
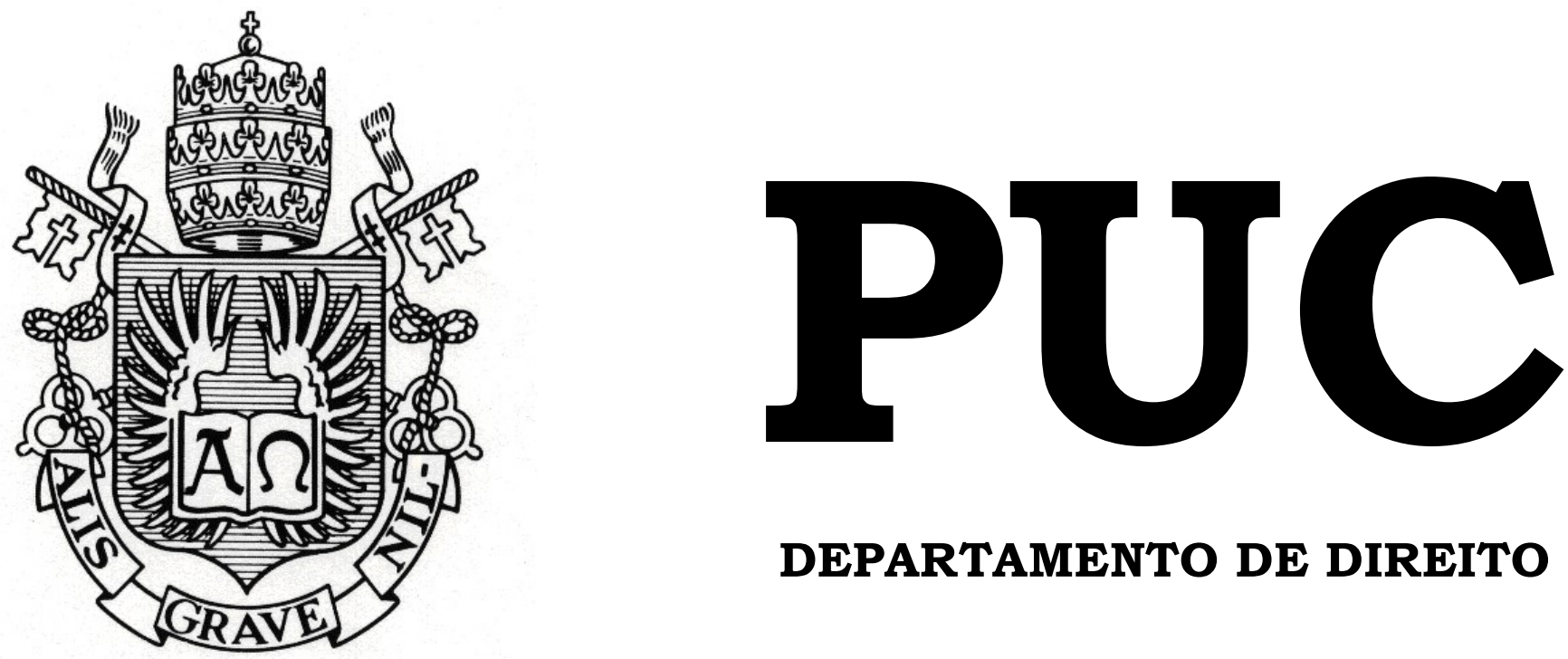

DEPARTAMENTO DE DIREITO

O DIRETO PENAL DO INIMIGO APLICADO NAS POLÍTICAS PÚBLICAS NO COMBATE ÀS ORGANIZAÇÕES CRIMINOSAS

\author{
por \\ JOÃO KARAM MACHADO FRANCO DE CAMARGO
}

ORIENTADOR: SERGIO CHASTINET DUARTE GUIMARÃES

2019.2

PONTIFÍCIA UNIVERSIDADE CATÓLICA DO RIO DE JANEIRO

RUA MARQUÊS DE SÃO VICENTE, 225 - CEP 22453-900

RIO DE JANEIRO - BRASIL 


\title{
O DIRETO PENAL DO INIMIGO APLICADO NAS POLÍTICAS PÚBLICAS NO COMBATE ÀS ORGANIZAÇÕES CRIMINOSAS
}

\author{
por \\ JOÃO KARAM MACHADO FRANCO DE CAMARGO
}

Monografia apresentada ao

Departamento de Direito da Pontifícia Universidade Católica do Rio de Janeiro (PUC-Rio) para a obtenção do Título de Bacharel em Direito.

Orientador: Sergio Chastinet Duarte Guimarães 


\section{DEDICATÓRIA}

À minha mãe Rita, mesmo não presente em corpo tenho certeza que seu espírito ilumina minha trajetória.

Ao meu pai Mario, por me ensinar verdadeiros valores que devem ser seguidos.

À Defensoria Pública do Estado do Rio de Janeiro, por me possibilitar enxergar a cruel realidade. 


\section{AGRADECIMENTOS}

Primeiramente, agradeço ao meu pai por todo suporte e apoio. Você é, sem dúvida, o grande responsável por me fornecer toda a estabilidade necessária para o meu desenvolvimento acadêmico e profissional.

Ao meu professor orientador Sergio por todas as elucidações e ajuda, não só nesse presente trabalho, como também em diversas outras oportunidades, certo que suas lições não serão esquecidas.

A todo corpo docente da Pontifícia Universidade Católica, em especial aos professores de Direito Penal, Processo Penal e Criminologia por me mostrarem que o direito também comporta críticas. Sem essa percepção eu não jamais estaria concluindo o curso jurídico.

A todos os defensores públicos com que tive a honra de trabalhar.

Por fim, gostaria de agradecer à minha namorada Jéssica por ter suportado toda minha instabilidade emocional nessa reta final da faculdade. Sem o seu apoio nada disso seria possível 


\section{RESUMO}

A presente monografia tem por objeto análise do direito penal do inimigo aplicado no combate as Organizações Criminosas no Brasil. Para isso se levou aspectos teóricos e históricos que auxiliam na compreensão do processo de formação dos inimigos presentes na sociedade brasileira, representados pela figura do traficante de drogas e do político corrupto, bem como suas consequências jurídicas e sociais. $\mathrm{O}$ intuito do presente artigo é demonstrar a relação entre esses indivíduos hostis aos olhos do direito e o suposto Crime Organizado.

PALAVRAS-CHAVE: Direito Penal do Inimigo - Organizações Criminosas Direito Penal - Processo Penal - Criminologia - Hiperencarceramento Letalidade Policial - Tráfico de Drogas-Colaboração Premiada - Corrupção. 


\section{SUMÁRIO}

Introdução _......................................................................................................................7

Capítulo 1 - Histórico do inimigo aos olhos do direito........................................9

Capítulo 2 - Histórico da criminalização das Organizações Criminosas...19

Capítulo 3 - O Inimigo no Combate às drogas..................................................25

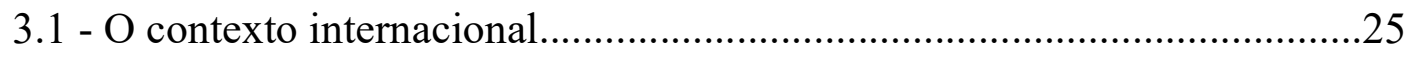

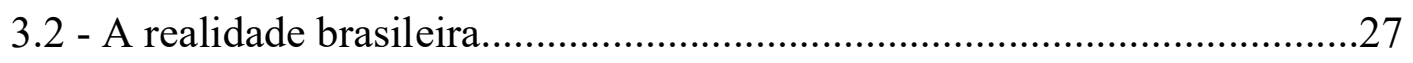

3.2.1 - Do Hiperencarceramento e Letalidade policial .........................28

3.2.2 - Das Raízes autoritárias e o Mito da imagem do traficante.........32

3.2.3 - Do racismo aplicado na política de drogas.................................36

Capítulo 4 - O Inimigo no Combate à corrupção..............................................38

4.1 - A colaboração premiada e o direito penal do inimigo................................ 39

4.2 - A construção do Inimigo político …………………………………….....47

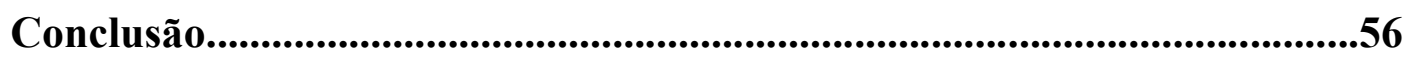

Bibliografia ......................................................................................................58 


\title{
LISTA DE ABREVIAÇÕES
}

\author{
AP - Ação Penal \\ PT - Partido dos Trabalhadores \\ PCC - Primeiro Comando da Capital \\ STF - Supremo Tribunal Federal
}




\section{INTRODUÇÃO}

A figura do inimigo parece se confundir com a própria história. Alguns especialistas defendem que quando o ser humano deixou de lado sua condição de caçador-coletor e começou o processo de domesticação de plantas e animais, em um processo chamado de Revolução Agrícola ocorrido a cerca de doze mil anos atrás, surgem os primeiros assentamentos permanentes. Começa a germinar a noção de propriedade nas mentes humanas e, decorrente dessa ideia, surge a necessidade de sua proteção frente aos seus vizinhos, estes sempre seres hostis. ${ }^{1}$ Desde então, a figura do inimigo sofreu diversas interpretações, com variações que dependem da época, lugar e interesse das classes dominantes.

Nota-se que, mesmo com milhares de anos de avanço civilizatório, a ilustração do inimigo tem grande influência na sociedade e sua presença no direito é inegável. Na ciência jurídica, encontra-se uma gama de discursos que racionalizam e legitimam tal concepção e refletem na Legislação, doutrina e jurisprudência. O afastamento de garantias legais é, muitas vezes, tolerado quando se trata de um "inimigo", pois em face desse indivíduo só resta o afastamento, a dominação ou sua exterminação.

Importante frisar que, apesar dessa perspectiva bélica ser muito difundida, é questionável sua compatibilidade com Estado Democrático de Direito, sendo algo mais próximo ao que se encontra no Estado de Polícia. A discussão acerca do inimigo se realça nas políticas públicas de segurança que, muitas vezes, são utilizadas como propaganda política de candidatos mais conservadores.

\footnotetext{
${ }^{1}$ HARARI, Y. N. Sapiens - Uma Breve História da Humanidade. 29a . ed. [S.1.]: Harper, 2011.página 66
} 
Raul Eugênio Zaffaroni e Nilo Batista, atentam para o caráter seletivo da criminalização ${ }^{2}$, bem como a efetuação da ideologia da Segurança Nacional, resultando em um estado de guerra permanente. ${ }^{3}$

Bem como na ficção de George Orwell que, em sua obra "1984", ao retratar uma sociedade distópica regida por um governo autoritário altamente controlador, ilustra um estado de Guerra permanente perpetrado pela Oceania. Nesse romance, é notório o interesse estatal na manutenção desse estado e de sua importância para o controle social, sendo relatado uma sociedade em que o Estado de Polícia chegou ao seu momento mais extremado. O lema pregado no partido dominante era "Guerra é paz, Liberdade é escravidão e Ignorância é força”. 4

Em discursos atuais encontram-se muitos grupos classificados como "inimigos" e o intuito do presente estudo é analisar, sob essa ótica, sua incidência nas políticas públicas de combate a Organizações Criminosas, em especial ao combate às drogas e corrupção. Para tanto, será analisada de uma perspectiva histórica, a construção do conceito de "direito penal do inimigo" e de "organização criminosa" até chegar aos moldes atuais.

\footnotetext{
${ }^{2}$ E. RAÚl ZAFFARONI, N. B. A. A. A. S. Direito Penal Brasileiro: primeiro volume - Teoria Geral do Direito Penal. 4ª ed. Rio de Janeiro: Revan, 2017.

${ }^{3}$ E. RAÚl ZAFFARONI, N. B. A. A. A. S. Direito Penal Brasileiro: primeiro volume - Teoria Geral do Direito Penal. $4^{\text {a }}$. ed. Rio de Janeiro: Revan, 2017. Página 59, parágrafo 3.

${ }^{4}$ ORWELL, G. 1984. São Paulo: Companhia das Letras, 2009.
} 


\section{Capítulo 1 - Histórico do inimigo aos olhos do direito}

De forma genérica, se tem como pressuposto do direito penal do inimigo, a presença de dois direitos, duas formas de aplicação da norma penal em um mesmo contexto jurídico. De um lado se encontra o direito cidadão, em que se vê a vigência de todas as garantias legais que são asseguradas ao indivíduo na persecução penal, de outro se vê o direito do inimigo, que por sua natureza, se afastou de modo permanente da sociedade, perdendo o status de cidadão, sendo permitido o afastamento de suas garantias.

Retomando aos tempos da Grécia antiga já se encontra relatos na presença de inimigos e a necessidade de defrontá-los juridicamente. Importante destacar que já é possível notar resquícios do que viria a ser tornar o Poder Punitivo. As leis draconianas, instituídas desde o século VII A.C já limitavam o poder familiar e transportava ao estado o direito a resolver um conflito penal. ${ }^{5}$

Para os gregos a pirataria era vista como um problema de extrema relevância e que necessitava ser combatido. A partir disso, surge a concepção do pirata como Hoste Humanis Generis (Inimigo da humanidade), podendo ser considerada uma remota idealização do direito penal do inimigo.

Ainda na era antiga, também se destaca a presença do poder punitivo na sociedade romana, o direito romano é notadamente a grande influência do sistema romano-germânico que temos hoje. Como grande potência da era antiga, Roma mantinha sua hegemonia através da expansão territorial, tendo conquistado grande parte da Europa, bem como parte da Ásia, África e Oriente Médio. Para dar cabo da organização de povos tão distintos, era aplicada uma legislação de lógica colonizadora. A usurpação por parte do Estado em resolver o conflito particular é resultado de uma poderosa verticalização interna.

\footnotetext{
${ }^{5}$ Lanni, Adrian. Law and Justice in the courts of Classical Athens. Cambridge University Press. Cambridge, 2006. Página 29
} 
Sobre o poder punitivo, Zaffaroni afirma o seguinte: "Desde a sua própria origem, o poder punitivo mostrou uma formidável capacidade de perversão, montada - como sempre - sobre um preconceito que impõe medo..."

A queda do império romano ocidental, ocorrida no século $\mathrm{V}$, em decorrência das invasões bárbaras, desencadeou o esfacelamento do direito romano, bem como o poder punitivo romano, que foi substituído pelas ordálias durante a idade média. O poder punitivo só retornará entre os séculos XII e XIII, com o nascimento da Monarquia. ${ }^{7}$

No século XIII nota-se o início da política criminal nos moldes de hoje, sendo esse o momento em que o Poder se colocará nas mãos do Estado, na figura da Igreja. Tem-se na Inquisição papel fundamental na efetivação do Poder Punitivo, influenciando inclusive as sociedades atuais (a ideia de delação nasce com a inquisição). ${ }^{8}$

Criada em 1215 pelo $4^{\circ}$ Concílio de Latrão, a Inquisição foi um tribunal especial e tinha por finalidade perseguir os Hereges Cátaros, sendo estes praticantes de "Heresias anti-hierárquicas". Diante da grande efetivação, os tribunais inquisidores se popularizaram e se espalharam por toda Europa. Em um segundo momento, a Inquisição concentrou suas atenções aos crimes de lesamajestade, momento esse que perseguiu os judeus e dissidentes políticos, incluindo nas colônias europeias. Por fim, em sua última etapa de controle, no século XVI, a inquisição adicionou as mulheres em sua lista de inimigos, em um

\footnotetext{
${ }^{6}$ ZAFFARONI, E. R. O Inimigo no Direito Penal. Tradução de Sérgio Lamarão. Rio de Janeiro: Revan, 2007.

${ }^{7}$ ANITUA, G. I. Histórias dos pensamentos criminológicos. Rio de Janeiro: Revan: Instituto Carioca de Criminologia, 2008.página 37

${ }^{8}$ ANITUA, G. I. Histórias dos pensamentos criminológicos. Rio de Janeiro: Revan: Instituto Carioca de Criminologia, 2008.Capítulo II.2
} 
momento em que a bruxaria passou a ser visto como um "mal cósmico" que precisava ser reprimido. ${ }^{9}$

O processo inquisitório começava com a prisão do "herege" e com o confísco de seus bens. Após sua detenção, se iniciava o interrogatório do acusado em busca de sua confissão, nesse procedimento, a tortura era permitida e vista como uma forma de obtenção da verdade. Outrossim, a condenação à fogueira era vista como purificação dos pecados.

Apesar da ocorrência da Inquisição ter sido diversa, variando de país e época, partilhava-se uma necessidade, de um "inimigo conveniente", pois era sobre essa classe que se justificava todo o maquinário burocrático repressão, que ao fim, reflete sobre toda a sociedade. Ademais, com o confisco dos bens, notase um interesse não só político, mas também econômico, na Inquisição.

Outro momento histórico merece destaque no que tange a teorização de inimigos no direito, a Alemanha de Hittler.

Pode-se afirmar que a Alemanha Nazista (1933-1945) tenha sido o Estado que aplicou o Direito Penal do Inimigo em seu grau máximo.

Após o fim da Primeira Guerra Mundial (1914-1918) o mundo se encontrou em um momento de crise profunda, tanto do ponto de vista econômico, quanto do ponto de vista social. Importantes mudanças ocorreram no contexto geopolítico, fato que alterou as relações e despertou sentimentos nacionalistas de revanchismo em diversas sociedades, principalmente às nações derrotadas na Guerra.

Nesse contexto de crise no entreguerras (1918-1939), o messianismo o começa a ganhar popularidade na Europa com a exaltação de líderes fortes e autoritários como única forma de sair da obscuridade trazida pela Primeira Guerra Mundial. Tais regimes assumiram discursos penais de caráter biologista,

\footnotetext{
${ }^{9}$ ANITUA, G. I. Histórias dos pensamentos criminológicos. Rio de Janeiro: Revan: Instituto Carioca de Criminologia, 2008. Capítulo II. 2
} 
elaborados de acordo com a estrutura inquisitorial e uma ideologia elaborada no Século XIX, baseado na periculosidade. Ocorrendo em diversas sociedades, independente de cunho ideológico, exercendo seu poder repressivo de forma genocida. ${ }^{10}$

Na Alemanha, tal fenômeno ocorre com Adolf Hittler. A partir de um discurso racista e de forte cunho nacionalista, o líder do partido nazista assume o poder na Alemanha no ano de 1933, poder esse que só se encerra com a sua morte em 1945. Durante esse período o líder alemão colocou em prática suas ideologias discriminatórias, perseguindo e eliminando todos os "inimigos da raça ariana".

Durante o regime nazista o direito alemão só possuía uma fonte, Adolf Hittler. A partir desse ideal, cabia ao direito penal se adaptar ao Estado Nazista. As leis em si possuíam aspecto secundário. Na prática, o Poder Repressivo do regime político era ilimitado. ${ }^{11}$

Nas palavras de Zaffaroni:

As leis penais destes autoritarismos mostravam só a cara visível do Sistema penal formal e alguma coisa do sistema penal paralelo, enquanto que, por trás dos panos, funcionava o mais terrível, o subterrâneo, sem lei e sem limites." ${ }^{12}$

No ano de 1933 foi montada a Comissão de Reforma do Direito Penal, composta de juristas alemães nazistas. Nessa Comissão foi elaborado um tratado para orientação jurídica no Estado Nazista, visando a proteção penal do Estado, do Partido e do Povo, estando excluídos os ditos inimigos. Dentre os termos do tratado, destaca-se medida que considerou ilícita qualquer ação contra a

\footnotetext{
${ }^{10}$ ZAFFARONI, E. R. O Inimigo no Direito Penal. Tradução de Sérgio Lamarão. Rio de Janeiro: Revan, 2007.página 53

${ }^{11}$ ZAFFARONI, E. R. O Inimigo no Direito Penal. Tradução de Sérgio Lamarão. Rio de Janeiro: Revan, 2007.

${ }^{12}$ ZAFFARONI, E. R. O Inimigo no Direito Penal. Tradução de Sérgio Lamarão. Rio de Janeiro: Revan, 2007.Página 34
} 
ideologia nazista. A partir desse momento só houve aumento da repressão aos considerados "antissociais". 13

No período do regime Social-nacionalista alemão se tornou comum a criação de tipos penais por analogia. A ideia de um direito penal de perigo, ao invés do direito penal do resultado estava impregnado, bem como a substituição de violação do bem jurídico pela noção de violação de um dever. Por fim, tinhase a percepção da pena como meio de eliminação dos "elementos impuros" da nação em virtude da política racial do regime. ${ }^{14}$

As Leis alemãs eram redigidas por juristas e tinham como objetivo agradar a autocracia (Hittler), mas também se dirigiam ao povo na forma de propaganda do regime, demonstrando assim, o caráter frontalista das leis, característico de regimes autocráticos. Tal técnica de propaganda se chamou de "volkisch". Utilizando-se da racionalização para justificar o regime político.

Eugênio Zaffaroni define tal técnica da seguinte forma: “... consiste em alimentar e reforçar os piores preconceitos para estimular publicamente a identificação do inimigo da vez."15

Dentre as leis penais formuladas pelos nazistas destacam-se a "Lei sobre o tratamento dos Estranhos à comunidade" e a "Lei do Delinquente Perigoso". A primeira se baseava em ideias biológicas/deterministas para justificar uma "higiene racial", com penas que variavam da castração a morte, já a segunda introduziu ao Código Penal Alemão o instituto da Medida de Custódia de Segurança. Tal Medida permitia a manutenção do delinquente em um centro de

\footnotetext{
${ }^{13}$ MACHADO, M. R. D. A. EDMUND MEZGER E O DIREITO PENAL DO NOSSO TEMPO. Revista Direito GV, São Paulo, v. 1, n. 1, p. 153-159, Maio 2005.Página 154

${ }^{14}$ MACHADO, M. R. D. A. EDMUND MEZGER E O DIREITO PENAL DO NOSSO TEMPO.

Revista Direito GV, São Paulo, v. 1, n. 1, p. 153-159, Maio 2005.Página 154

${ }^{15}$ ZAFFARONI, E. R. O Inimigo no Direito Penal. Tradução de Sérgio Lamarão. Rio de Janeiro: Revan, 2007.página 57
} 
trabalho por tempo indeterminado após o cumprimento de sua pena em razão da sua periculosidade. ${ }^{16}$

Esse instituto legal legitimou os campos de concentração, permitindo a internação e morte de milhares de pessoas. ${ }^{17}$

Outrossim, relações sexuais entre judeus e alemães eram puníveis com a morte. Tais atos eram considerados "ultrajes" à raça superior ariana. ${ }^{18}$

O principal componente do direito penal nazista era o antissemitismo. Hittler pregava o ódio ao povo judaico e depositou sobre eles e aos socialistas a derrota alemã na Primeira Guerra Mundial, de acordo com ele, a Alemanha havia sido traída por eles. A partir disso, o povo judeu foi culpado por todos os males ocorridos no país e a consequência foi uma política voltada para sua eliminação.

A Escola Positiva da criminologia, que tem início no século XIX e tem como principais nomes Cesare Lombroso, conhecido como o fundador da criminologia com, Enrico Ferri e Raffaele Garófalo. Com base em teorias "científicas", o positivismo se vale da ideia do crime como fenômeno natural e da pena como instrumento de defesa social, aplicando o método indutivo experimental, com enfoque no comportamento do criminoso.

Noções de "delinquente natural”, análises biológicas e as classificações dos indivíduos, são bases que fundamentam a ideia determinista acerca do crime/criminoso da Escola Positiva. Notórias são as influências racistas dessa Escola, visto que pregava a inferioridade do estranho perante o coletivo.

\footnotetext{
${ }^{16}$ MACHADO, M. R. D. A. EDMUND MEZGER E O DIREITO PENAL DO NOSSO TEMPO.

Revista Direito GV, São Paulo, v. 1, n. 1, p. 153-159, Maio 2005.

${ }^{17}$ MACHADO, M. R. D. A. EDMUND MEZGER E O DIREITO PENAL DO NOSSO TEMPO.

Revista Direito GV, São Paulo, v. 1, n. 1, p. 153-159, Maio 2005.

${ }^{18}$ MACHADO, M. R. D. A. EDMUND MEZGER E O DIREITO PENAL DO NOSSO TEMPO.

Revista Direito GV, São Paulo, v. 1, n. 1, p. 153-159, Maio 2005.
} 
Dos principais nomes do positivismo criminológico, Garófalo se destaca por ter tido grande influência nos movimentos de direita, abarcando o Nazismo, ocorrido na Alemanha. ${ }^{19}$

Em sua obra destaque, o autor conceitua a ideia de "delito natural", entendendo que a defesa social era a luta contra seus "inimigos naturais", demonstrando assim um racismo idealista. Tal conceito era regido mais pelos sentimentos do que por critérios descritivos, ele afirmava que os delitos não eram os mesmos nas sociedades, pois cada uma possui valores diferentes. A partir disso, advertia que os "inimigos" podem variar de sociedade para sociedade. $^{20}$

Para Garófalo, delitos são tudo aquilo que viola os dois pilares naturais: a Piedade - referente à vida; e a probidade - referente à propriedade.

Ademais, sua "maior" contribuição para a Escola Positiva foi a formulação do conceito de periculosidade, tão cara ao direito penal nacionalsocialista. $\mathrm{O}$ autor defendia que a pena não deveria ser proporcional ao delito cometido, e sim à periculosidade do agente. Tal ideia fundamenta a "lei do Delinquente perigoso" no direito alemão e justifica a ida de pessoas aos campos de concentração. ${ }^{21}$

No livro "O Inimigo do Direito Penal" Zaffaroni descreve o "inimigo" de Garófalo como um "inimigo ôntico", descrevendo que ele assim é definido em razão de sua natureza e não por escolha política. No mesmo livro o autor argentino destaca que a técnica "Volkish" em muito se assemelha com esse discurso de combate às "classes perigosas". Tais classes não seriam somente os

\footnotetext{
${ }^{19}$ ZAFFARONI, E. R. O Inimigo no Direito Penal. Tradução de Sérgio Lamarão. $2^{\text {a }}$. ed. Rio de Janeiro: Revan, 2007. 224 p. página 102

${ }^{20}$ MAURÍCIO, J. L. R. Positivismo Criminológico: as ideias de Lombroso, Ferri e Garófalo. Olhares Plurais, Maceió, v. 1, n. 12, p. 59-69, julho 2015.

${ }^{21}$ ZAFFARONI, E. R. O Inimigo no Direito Penal. Tradução de Sérgio Lamarão. $2^{\mathrm{a}}$. ed. Rio de Janeiro: Revan, 2007. 224 p. página 105
} 
delinquentes graves, mas também os "indesejáveis", os que não teriam se adaptado à vida em sociedade. ${ }^{22}$

Outrossim, dentre os juristas alemães do regime nazista, se destaca Edmund Mezger, relevante nome da criminologia do período. O autor teve papel determinante nas alterações ocorridas no ordenamento alemão. Ele participou da Comissão da Reforma do Direito Penal (1933), bem como na elaboração das principais leis criminais nazistas.

A tarefa principal de Mezger foi desenvolver a teoria legitimadora da política criminal racista implantada na Alemanha. Conceitos como "inimizade ao direito" e "cegueira ao direito" eram utilizados para legitimar a repressão aos “inimigos do Estado" (inerentes ao conceito de inimigo ôntico), que tinham atitudes em desacordo com o "instinto alemão". A tarefa repressiva sempre tinha como escopo a ideia de superioridade alemã. ${ }^{23}$

Por fim, outro ponto de relevância histórica é a teorização do "Direito Penal do Inimigo", realizada na Alemanha no final dos anos 1980.

Desenvolvida pelo autor alemão Gunther Jakobs, o Direito Penal do Inimigo foi elaborada como tese de política pública de combate à criminalidade, pugnando, em síntese, por maior rigor no tratamento do agente delituoso. Para ele, a função primordial do direito penal é a proteção da própria norma.

Professor de direito penal e Filosofia do direito na faculdade de Bonn, na Alemanha, Gunther constrói sua argumentação com base nos pensamentos contratualistas, tendo Kant como sua principal referência.

$\mathrm{O}$ autor propõe uma divisão entre o direito penal do cidadão e o direito penal do inimigo, tratando ambos como dois polos de um só mundo, duas tendências de um contexto jurídico penal.

\footnotetext{
${ }^{22}$ ZAFFARONI, E. R. O Inimigo no Direito Penal. Tradução de Sérgio Lamarão. $2^{\text {a }}$. ed. Rio de Janeiro: Revan, 2007. 224 p.página 104

${ }^{23}$ ZAFFARONI, E. R. O Inimigo no Direito Penal. Tradução de Sérgio Lamarão. $2^{\mathrm{a}}$. ed. Rio de Janeiro: Revan, 2007. 224 p.página 106-107
} 
Para Jakobs, o Direito Penal do Cidadão implica em uma visão tradicional, garantista e com observância de todos os princípios fundamentais que lhe são pertinentes. Em contraponto, o Direito Penal do Inimigo importa na supressão de direitos e garantias oferecidas ao réu. $\mathrm{O}$ afastamento desses princípios se dá pelo fato de que determinados grupos de pessoas devem ser vistos como inimigos do Estado, não como cidadãos.

Contratualistas como Rousseu, Fichte e Hobbes influenciaram no trabalho do professor alemão, contudo percebe-se na lógica kantiana sua maior inspiração. ${ }^{24}$

Kant idealizava o contrato social como regulação. Nele, qualquer vizinho que se encontre em estado natural, ou seja, que não tenha anuído com o estado comunitário, pode ser compelido a se retirar. Para ele, o Estado Natural é ilegítimo, por isso deve ser tratado como ameaça.

Nas palavras de Gunther: "O Direito Penal do cidadão é o Direito de todos, o Direito penal do inimigo é daqueles que o constituem contra o inimigo: frente ao inimigo só a coação física, até chegar à guerra." 25

Depreende-se do trecho um raciocínio de verdadeiro estado de guerra no que tange a política criminal estatal. Diante da construção do referido cenário, pugna o autor por utilização de medidas excepcionais de coação ao lidar-se com determinados indivíduos, não mais considerados cidadãos, mas sim rotulados como "inimigos".

Dentre as medidas, o autor defende a antecipação da punição. Para ele, a pena se dirige à frente, à prevenção de fatos futuros e não à sanção de fatos cometidos. Outrossim, pugna pela desproporcionalidade das penas bem como

\footnotetext{
${ }^{24}$ GUNTHER JAKOBS, M. C. M. Direito Penal do Inimigo: noções e críticas. $2^{\mathrm{a}}$. ed. Porto Alegre: Livraria do advogado, 2007.pgs. 26-30

${ }^{25}$ GUNTHER JAKOBS, M. C. M. Direito Penal do Inimigo: noções e críticas. 2a . ed. Porto Alegre: Livraria do advogado, 2007.página 30
} 
na criação de leis severas destinados à determinado grupo taxado socialmente como "inimigo". ${ }^{26}$

Importante destacar que a tese de Jakobs sofreu graves críticas de juristas, tanto na Alemanha, como em diversos outros países.

Diante do exposto nota-se, por parte desses exemplos históricos, que a presença do inimigo sempre se fez necessária para legitimar qualquer instrumento de repressão. Além dos citados, diversos outros momentos podem ser elencados na história. Tendo como parâmetro norteador o Estado de Direito, é notória a sua não compatibilidade com a figura do inimigo.

${ }^{26}$ GUNTHER JAKOBS, M. C. M. Direito Penal do Inimigo: noções e críticas. 2a . ed. Porto Alegre: Livraria do advogado, 2007.páginas 39-41 


\section{Capítulo 2 - Histórico da criminalização de organizações criminosas}

No tocante ao conceito de organização criminosa é importante destacar que a criminologia não logrou êxito em conceituar crime organizado. $\mathrm{O}$ que se tem na realidade é uma inútil tentativa em classificar um número incerto de fenômenos delitivos em uma categoria. As especificidades apresentadas em cada caso e classificadas como atuação do crime organizado, impossibilita a ciência penal em conceituá-lo. O criminólogo argentino Raul Eugênio Zaffaroni, classifica a categoria como "frustrada". ${ }^{27}$

Trata-se de um pseudoconceito, inventado pelo jornalismo e pelos políticos da primeira metade do século passado, sobre a qual a criminologia nunca tinha chegado a um acordo, mas que agora tem sido adotado legislativamente para abarcar hipóteses conflitivas heterogêneas $[\ldots]^{28}$

A noção de crime organizado é difundida por meio alguns atores sociais que que se beneficiam com essa narrativa. Importante a lição trazida por Zaffaroni quando afirma que a mídia, os autores de ficção, os políticos e as agências penais são as fontes de definição de crime organizado, sendo que cada um desses atores possui interesses próprios. ${ }^{29}$

Sobre a origem discursiva do crime organizado Juarez Cirino dos Santos dá a seguinte lição:

$\mathrm{Na}$ verdade, existem dois discursos sobre crime organizado estruturados nos polos americano e europeu do sistema capitalista globalizado: o discurso americano sobre organized crime, definido como conspiração nacional de etnias estrangeiras, e o discurso italiano sobre crimine organizzato, que tem por objeto de estudo original a Máfia siciliana. O estudo desses discursos pode contribuir para desfazer o mito do crime organizado, difundido pela mídia, pela literatura de ficção, por políticos e

\footnotetext{
${ }^{27}$ ZAFFARONI, E. R. "Crime Organizado": uma categoria frustrada. In: Discursos sediciosos: crime, direito e sociedade. Rio de Janeiro: Relume Dumará, v. 1, 1996. p. 45-67.

${ }^{28}$ ZAFFARONI, E. R. O Inimigo no Direito Penal. Tradução de Sérgio Lamarão. 2a . ed. Rio de Janeiro: Revan, 2007. 224 p.página 63
}

${ }^{29}$ ZAFFARONI, E. R. "Crime Organizado": uma categoria frustrada. In: Discursos sediciosos: crime, direito e sociedade. Rio de Janeiro: Relume Dumará, v. 1, 1996. p. 45-67. 
instituições de controle social e, desse modo, reduzir os efeitos danosos do conceito de crime organizado sobre os princípios de política criminal do direito penal do Estado Democrático de Direito. ${ }^{30}$

O termo "crime organizado" foi criado pela criminologia norte-americana durante o período conhecido pela "lei seca" em que se imperava o Volstead act (1920), na qual proibia a produção, a comercialização, a estocagem e o consumo de bebida alcoólica. Impulsionado por um discurso de origem moral-religiosa, a política proibicionista teve como grande influência o puritanismo protestante, muito presente no território norte-americano. ${ }^{31}$ Contudo se percebe o interesse de controle social, bem como geopolítico por detrás dessas políticas.

$\mathrm{O}$ contexto à época era marcado por tensões sociais decorrentes do processo de industrialização e concentração urbana (artigo sociologia proibicionismo), bem como a vinda de imigrantes de origem europeia, em especial italianos.

O discurso do crime organizado teve como alvo grupos que se envolviam com o mercado ilícito, criado a partir da proibição. Desenvolveu-se um estigma ao se tratar desses tipos de criminosos, que, majoritariamente pertenciam a grupos étnicos minoritários. Sob a lógica do inimigo, tais grupos eram vistos como danosos para a sociedade norte-americana e precisavam ser reprimidos.

O discurso americano do organized crime, originário das instituições de controle social, nasce com o objetivo de estigmatizar grupos sociais étnicos (especialmente italianos), sob o argumento de que o comportamento criminoso não seria uma característica da comunidade americana, mas de um submundo constituído por estrangeiros, aqueles maus cidadãos que ameaçavam destruir a comunidade dos bons cidadãos. Esse conceito xenófobo revelou sua utilidade: teorias criminológicas fundadas na noção de subcultura e de desorganização social definiram o crime organizado como conspiração contra o povo e o governo americanos, promovida por

\footnotetext{
${ }^{30}$ Palestra proferida no 1o Fórum Latino-Americano de Política Criminal, promovido pelo IBCCRIM, de 14 a 17 de maio de 2002, em Ribeirão Preto, SP.

${ }^{31}$ D'ELIA FILHO, O. Z. Acionistas do nada: quem são os traficantes de droga. $3^{\text {a }}$. ed. Rio de Janeiro: Revan, 2007. 140p. página 81
} 
organizações secretas nacionais, centralizadas e hierarquizadas de grupos étnicos estrangeiros. ${ }^{32}$

Essa associação entre crime organizado e conspiração nacional serviu como base para diversos políticos e foi difundida pela mídia, influenciando o imaginário social acerca do perigo desses criminosos, poderosos e organizados. $^{33}$

No âmbito cultural, o que se viu foi a dramatização e espetacularização do crime organizado, sendo explorado tanto pela mídia quanto por autores de ficção. A popularidade do tema é inegável visto a atenção dada pelos jornais da época, bem como a inúmera quantidade de filmes e livros que foram feitos sobre essa temática, desenvolvendo, assim, o paradigma mafioso.

Após a legalização do álcool, com a revogação do Volstead act, em 1933, os Estados Unidos realocaram suas políticas repressivas visando um outro mal social, agora as drogas. Iniciou-se, dessa vez através de um argumento médicocientífico, um processo de proibição de uma série de narcóticos (ópio, maconha, cocaína, dentre outros), bem como uma influência da política externa nesse sentido.

Importante destacar que apesar das políticas repressivas com relação às bebidas alcoólicas terem tido pouca influência em um contexto global discurso de combate às drogas foi bem recebido pela comunidade internacional. Como bem resume Juarez Cirino:

Extinto o mercado ilícito e os lucros fabulosos da criminalização do álcool durante a chamada lei seca, o perigo atribuído ao organized crime deslocou o eixo para o tráfico de drogas, um novo mercado ilícito com lucros fabulosos criado pela política de criminalização das drogas, promovida a nível planetário pelo governo americano, sob

\footnotetext{
32 Palestra proferida no 1o Fórum Latino-Americano de Política Criminal, promovido pelo IBCCRIM, de 14 a 17 de maio de 2002, em Ribeirão Preto, SP.

${ }^{33}$ Palestra proferida no 1o Fórum Latino-Americano de Política Criminal, promovido pelo IBCCRIM, de 14 a 17 de maio de 2002, em Ribeirão Preto, SP.
} 
o mesmo paradigma da conspiração contra o american way of life, agora com conexões internacionais. ${ }^{34}$

O que se percebeu na prática, é que tais políticas serviram de justificativa para um fortalecimento do efetivo repressivo estatal em face de alguma minoria étnica associada ao consumo da droga, esta, não absorvida pela lógica capitalista. Diante daí, se vê uma maior rigidez no controle por parte dos países industrializados após a década de $1950 .^{35}$

Nos anos 1970, com base em um modelo médico-jurídico, que passou a distinguir o consumidor do traficante, estabeleceu-se o modelo de Guerra às drogas, com a implementação de políticas oriundas da lógica de "Lei e Ordem" norte-americana, esse raciocínio somente escalonou durante as décadas seguintes. É dentro deste contexto bélico que estamos inseridos atualmente.

Importante destacar como o discurso norte-americano exerce papel central na perspectiva de combate às organizações criminosas presente em escalas globais nos dias de hoje. Outrossim, interessante notar como o discurso de combate do crime organizado possui uma relação intrínseca com a política proibicionista, sendo, em sua origem, uma coisa só.

O discurso punitivista decorrente do crime organizado foi bem recebido pelos países periféricos, principalmente pelos da América Latina. Na Lição de Juarez Cirino: "O conceito de crime organizado, desenvolvido no centro do sistema de poder econômico e político globalizado, recebeu na periferia desse sistema homenagens de cidadania, como se fosse um discurso criminológico próprio." 36

\footnotetext{
${ }^{34}$ Palestra proferida no 1o Fórum Latino-Americano de Política Criminal, promovido pelo IBCCRIM, de 14 a 17 de maio de 2002, em Ribeirão Preto, SP.

${ }^{35}$ D'ELIA FILHO, Orlando Zaccone. Acionistas do nada: quem são os traficantes de droga. $3^{\mathrm{a}}$. ed. Rio de Janeiro: Revan, 2007. página 84

${ }^{36}$ Palestra proferida no 1o Fórum Latino-Americano de Política Criminal, promovido pelo IBCCRIM, de 14 a 17 de maio de 2002, em Ribeirão Preto, SP.
} 
No Brasil a relação do crime organizado, historicamente, teve grande relação às drogas, recorte este que será abordado no próximo capítulo do presente artigo. Contudo, se pode extrair um exemplo no art. $33 \S 4^{\circ}$ da Lei de drogas, em que o termo "organização criminosa" foi utilizado sem definição legal no direito pátrio à época, algo que só irá acontecer no ano de 2013, com a promulgação da atual Lei de Organizações Criminosas.

“Art. 33 - Importar, exportar, remeter, preparar, produzir, fabricar, adquirir, vender, expor à venda, oferecer, ter em depósito, transportar, trazer consigo, guardar, prescrever, ministrar, entregar a consumo ou fornecer drogas, ainda que gratuitamente, sem autorização ou em desacordo com determinação legal ou regulamentar:

Pena - reclusão de 5 (cinco) a 15 (quinze) anos e pagamento de 500 (quinhentos) a 1.500 (mil e quinhentos) dias-multa.

$\S 4^{\circ}$ Nos delitos definidos no caput e no $\S 1^{\circ}$ deste artigo, as penas poderão ser reduzidas de um sexto a dois terços, desde que o agente seja primário, de bons antecedentes, não se dedique às atividades criminosas nem integre organizacão criminosa. (grifos próprios Lei 11.343/2006)

Curioso é o fato de que quando a Lei de drogas entrou em vigor, não havia qualquer legislação nacional que elucidasse o tema referente à organização criminosa. A lei $\mathrm{n}^{\circ}$ 9.034/1995, vigente à época não trazia qualquer definição sobre o termo. Conforme depreende-se do artigo $1^{\circ}$ da lei revogada. "Art. $1^{\circ}$ Esta lei define e regula meios de prova e procedimentos investigatórios que versarem sobre crime resultante de ações de quadrilha ou bando.” (Lei 9.034/1995)

A fonte de definição acerca das organizações criminosas foi a convenção internacional de Palermo, internalizada pelo decreto $\mathrm{n}^{\mathrm{o}} 5015 / 2004$, e isso perdurou até a promulgação da atual Lei de Organizações criminosas (Lei 12.850/2013), que revogou à lei 9.034/1995, bem como trouxe uma definição legal. 
Art. $1^{\circ}$ Esta Lei define organização criminosa e dispõe sobre a investigação criminal, os meios de obtenção da prova, infrações penais correlatas e o procedimento criminal a ser aplicado.

$\S 1^{\circ}$ Considera-se organização criminosa a associação de 4 (quatro) ou mais pessoas estruturalmente ordenada e caracterizada pela divisão de tarefas, ainda que informalmente, com objetivo de obter, direta ou indiretamente, vantagem de qualquer natureza, mediante a prática de infrações penais cujas penas máximas sejam superiores a 4 (quatro) anos, ou que sejam de caráter transnacional. (Lei 12.850/2013)

Ademais, A lei de Organizações criminosas introduz outras novidades à legislação nacional. A lei 12.850/2013 também tipifica o crime e estabelece outros meios de prova, com institutos da delação premiada, ação controlada e infiltração de agentes.

Historicamente, é inegável a relação entre as organizações criminosas e a política de proibição, contudo, fenômenos jurídicos mais recentes demonstram que a política repressiva ao crime organizado possui outros vieses punitivistas.

A seguir será motivo de análise o contexto do inimigo no tocante as políticas públicas visando a redução do tráfico de drogas. 


\section{Capítulo 3 - 0 inimigo no combate às drogas.}

\section{1 - O contexto internacional}

A humanidade sempre utilizou de substâncias psicoativas para as mais diversas finalidades, passando por médicas até ritualísticas. Há relatos da utilização de entorpecentes nas mais diferentes sociedades e momentos. ${ }^{37}$ Compreender essa relação histórica da humanidade com esses fármacos é essencial para compreender o quão recente é a criação deste modelo repressivo dos dias atuais.

$\mathrm{O}$ debate quanto à regulamentação das substâncias consideradas narcóticos, tem início no século XIX, período marcado pelo processo de industrialização em escala global. Apesar disso, políticas mais repressivas só começaram a ser implementadas após a Segunda Guerra Mundial. ${ }^{38}$

Conforme já antecipado, a política proibicionista tem origem nos Estado Unidos e quando passou a ter como alvo os narcóticos tomaram proporções globais, sendo grande influenciador de políticas repressivas mundo afora. A movimentação geopolítica realizada pelos norte-americanos, bem como a popularidade do discurso penal para fins políticos podem ser considerados como impulsionadores desse fenômeno, até chegarmos na realidade bélica dos dias atuais.

A grande virada repressiva com relação às drogas se inicia no governo de Richard Nixon (1969-1974), quando declarou, em junho de 1971, publicamente que o abuso de drogas era "Inimigo público número um” nos EUA. Tal

\footnotetext{
${ }^{37}$ ESCOHOTADO, A. Historia general de las drogas. $7^{\mathrm{a}}$. ed. Madrid: Alianza Editorial, 1998.

${ }^{38}$ DA CRUZ, J. H. T.; AZEVEDO, G. A política proibicionista e o mercado ilícito de drogas. Revista Brasileira de Sociologia do Direito, Porto Alegre, v. 2, p. 99-108, jan./jun. 2015.página 101
} 
manifestação iniciou a “Guerra às Drogas”, período esse, que perdura até os dias de hoje.

Essa narrativa teve grande influência em países marginalizados, em especial nos latino-americanos visto que, pelo contexto de Guerra Fria, conviveram até os anos 1980 com ditaduras cívico-militares financiadas pelos EUA. Nesse período, os comunistas eram os grandes inimigos do estilo de vida norte-americano e serviram como justificativa para implementação de regimes não democráticos em diversos países do continente. À repressão às drogas nesse período se relacionava com uma questão de segurança nacional. Conforme ensina o criminólogo argentino Raúl Eugênio Zaffaroni:

[...] o traficante era um agente que pretendia debilitar a sociedade ocidental, o jovem que fumava maconha era um subversivo, guerrilheiros eram confundidos com e identificados a narcotraficantes (a narcoguerrilha) etc. À medida que se aproximava a queda do muro de Berlim, tornou-se necessário eleger outro inimigo para justificar a alucinação de uma nova guerra e manter os níveis repressivos elevados. Para isso, reforçou-se a guerra contra a droga ${ }^{39}$

Apesar de Nixon ter dado um passo para uma política visando a restrição quanto às atividades relacionadas às drogas, é no governo de Ronald Reagan (1981-1989), que essa política bélica será vista como prioridade. A intervenção estadunidense em políticas públicas de segurança na Colômbia nesse período evidencia isso, visto que muitos traficantes colombianos foram e são, até hoje, extraditados e julgados em solo norte-americano.

Além de intervenções, a política repressiva norte-americana influenciou na redação de legislações no continente, trazendo uma certa uniformidade legislativa entre os países quando o tema referente são as drogas, alterando tanto questões de direito material, quanto questões de direito processual. Zaffaroni ensina:

Estabeleceu-se uma aberrante legislação penal autoritária, que poucos se animaram a denunciar, ameaçados de serem acusados de partícipes e encobridores do narcotráfico

\footnotetext{
${ }^{39}$ ZAFFARONI, E. R. O Inimigo no Direito Penal. Tradução de Sérgio Lamarão. $2^{\mathrm{a}}$. ed. Rio de Janeiro: Revan, 2007. 224 p.página 51
} 
ou de ser presos, ao melhor estilo inquisitorial, o que aconteceu inclusive com magistrados, fiscais e acadêmicos. ${ }^{40}$

Assim como se fez com o estereótipo mafioso, teve que se construir o perfil do narcotraficante para que a implementação de políticas penais autoritárias fosse tolerada pelo tecido social. Zaccone resume essa generalização aplicada ao traficante em sua obra "Acionistas do nada: quem são os traficantes de drogas", conforme se percebe no seguinte trecho:

No comando deste grande negócio é identificada, em seu aspecto político e legal, a figura do "narcotraficante", cujo estereótipo, construído pelo discurso oficial e divulgado pela mídia, aponta para o protótipo do criminoso organizado, violento poderoso e enriquecido através da circulação ilegal desta mercadoria, conhecida em nossa legislação outrora como 'entorpecente' e hoje, genericamente, como "droga". ${ }^{41}$

É certo que, após os atentados contra as Torres Gêmeas em Nova York no ano de 2001, o principal adversário ao estilo de vida estadunidense passou a ser o terrorista, que se tornou centro das novas políticas repressivas. Importante destacar que atualmente alguns estados norte-americanos, bem como alguns países pelo mundo, em especial no continente europeu, estão revisando os modelos de políticas públicas com relação às drogas.

Apesar desse horizonte menos repressivo em alguns países, em outros, ainda se percebe a manutenção dessa lógica bélica ao se pensar políticas públicas sobre drogas. O Brasil é exemplo de uma completa imersão na lógica de guerra quando o assunto são as substâncias classificadas como narcóticos, conforme será exposto a seguir.

\section{2 - A realidade brasileira (Do hiperencarceramento, da letalidade policial e raízes autoritárias)}

\footnotetext{
${ }^{40}$ ZAFFARONI, E. R. O Inimigo no Direito Penal. Tradução de Sérgio Lamarão. $2^{\text {a }}$. ed. Rio de Janeiro: Revan, 2007. 224 p.página 52

${ }^{41}$ D'ELIA FILHO, O. Z. Acionistas do nada: quem são os traficantes de droga. $3^{\mathrm{a}}$. ed. Rio de Janeiro: Revan, 2007. 140 p.página 11
} 
No tocante à repressão às drogas o Brasil se valeu desde cedo da sua seletividade e utilização como instrumento de controle social. No ano de 1830, a câmara municipal do Rio de Janeiro, promulgou o que veio a ser a primeira legislação que criminalizou a maconha no mundo, chamada à época de "pito de pango". 42

O consumo da substância era comum entre os escravos africanos, que vieram massivamente ao país durante a diáspora africana e serviram como mão de obra para uma economia baseada na monocultura. Segue-se, como via de regra, o vínculo entre a criminalização de substâncias e minorias étnicas. Importante destacar que política de drogas no Brasil é um dos grandes responsáveis pelo problema carcerário.

\subsection{1 - Do Hiperencarceramento e Letalidade policial}

É inegável a crise atual do sistema carcerário brasileiro, dados do INFOPEN, dão conta que, no primeiro semestre de 2017, 726.354 mil pessoas estavam inseridas no sistema prisional. Dentre elas, um total de 136.149 mil de homens e mulheres que foram condenados ou estão sendo processados pelo crime de tráfico de drogas, cerca de $18 \%$ da população prisional, a maior na classificação conforme os tipos legais. ${ }^{43}$

$\mathrm{Na}$ enorme gama de tipos penais que existem na legislação brasileira, ver que somente o crime de tráfico representa quase $1 / 5$ do total de presos, demonstra a completa imersão na narrativa repressiva referente aos

\footnotetext{
42 VILLELA, G. Pito do Pango' na década de 30, maconha era vendida em herbanários do Rio. O Globo, Rio de Janeiro, 23 julho 2014. Disponivel em: <https://acervo.oglobo.globo.com/em-destaque/pito-dopango-na-decada-de-30-maconha-era-vendida-em-herbanarios-do-rio-13352181>.

${ }^{43}$ Levantametno nacional de informações penitenciárias, atualizaçõa junho de 2017. Ministério da Justiça e Segurança Pública, Departamento penitenciário Nacional. [S.1.], p. 87. 2019.
} 
entorpecentes. É inegável a contribuição da política proibicionista na realidade do hiperencarceramento nacional.

$\mathrm{O}$ modelo bélico de repressão ao tráfico não se restringe aos altos números de encarceramento. No Brasil é notório o envolvimento de membros de agências policiais no que Zaffaroni chama de Sistema penal subterrâneo.

Nas palavras do criminólogo argentino:

Este é o sistema penal subterrâneo, que institucionaliza a pena de morte (execuções sem processo), desaparecimentos, torturas, sequestros, roubos, saques, tráfico de drogas, exploração do jogo, da prostituição etc. A magnitude e as modalidades do sistema penal subterrâneo dependem das características de cada sociedade e de cada sistema penal, da força das agências judiciais, do equilíbrio de poder entre suas agências, dos controles efetivos entre os poderes etc. ${ }^{44}$

Em relatório referente a execuções extrajudiciais, homicídios e outras violações de direitos humanos praticados pela Polícia Militar na cidade do Rio de Janeiro realizado pela Anistia Internacional consta:

Execuções extrajudiciais cometidas por policiais são frequentes no Brasil. No contexto da chamada "guerra às drogas", a Polícia Militar tem usado a força letal de forma desnecessária e excessiva, provocando milhares de mortes ao longo da última década. As autoridades utilizam com frequência os termos "auto de resistência" ou "homicídio decorrente de intervenção policial" (usados nos registros de mortes provocadas por policiais em serviço e justificadas com base na legítima defesa) como uma "cortina de fumaça" para encobrir execuções extrajudiciais promovidas pelos policiais. ${ }^{45}$

No ano de 2016, foi instaurado no Senado Federal a Comissão Parlamentar de Inquérito do Assassinato de Jovens (CPIADJ), a fim de identificar os problemas sobre os altos índices de violência contra os jovens no Brasil. Dentre diversos pontos levantados no relatório final da CPI, a relação intrínseca entre a violência e a repressão ao tráfico de drogas se destaca. A

\footnotetext{
${ }^{44}$ ZAFFARONI, E. R. O Inimigo no Direito Penal. Tradução de Sérgio Lamarão. $2^{\mathrm{a}}$. ed. Rio de Janeiro: Revan, 2007. 224 p. página 70

${ }^{45}$ VOCÊ matou meu filho: homicídios cometidos pela polícia na cidade do Rio de Janeiro. Anistia Internacional, Rio de Janeiro, 2015.
} 
omissão estatal em relação a determinadas regiões se associa com a violência coercitiva aplicada nestes lugares, considerados sob domínio de organizações criminosas. ${ }^{46}$

A questão geográfica exerce fator essencial nesse modelo repressivo visto que as classes mais abastadas não convivem com a violência decorrente da guerra contra os narcóticos, o caso das favelas cariocas são os exemplos mais conhecidos nacionalmente. Desta forma, a normalização e até apoio aos “excessos" policiais são perpetrados por grande parte da classe média. Uma amostra concreta dessa realidade consta na pesquisa realizada pela Datafolha no ano de 2016, que consta que $57 \%$ da população brasileira acredita na famosa afirmação "bandido bom é bandido morto". ${ }^{47}$

Os altos índices de letalidade policial, bem como os números de encarceramento são frutos dessa política repressiva às drogas e justificadas a partir da imagem estereotipada de um inimigo extremamente perigoso à estabilidade social.

A relativização permissionária no sentido de obtenção dos meios de prova é admitida quando o assunto são as drogas. Dentro dessa lógica, exemplos de expedição de mandados de busca e apreensão coletivos para determinadas áreas consideradas perigosas são encontrados na jurisprudência brasileira, mesmo sendo manifestamente ilegais por ferirem a regra do artigo 243, do Código de Processo Penal. Em uma nítida violação do princípio da presunção de inocência.

A própria valoração da prova é relativizada em detrimento do sentimento punitivista. A súmula 70 do Tribunal de Justiça do Estado do Rio de Janeiro é exemplo cristalino disso, possuindo a seguinte redação:

\footnotetext{
${ }^{46}$ FARIAS, L. Relatório Final CPI assassinato de jovens. Senado Federal. [S.1.], p. 155. 2015.

${ }^{47}$ Para 57\% dos brasileiros, 'bandido bom é bandido morto', diz Datafolha. Portal de notícias G1, São Paulo, 02 novembro 2016. Disponivel em: <http:/g1.globo.com/sao-paulo/noticia/2016/11/para-57dos-brasileiros-bandido-bom-e-bandido-morto-diz-datafolha.html $>$.
} 
"O fato de restringir-se a prova oral a depoimentos de autoridades policiais e seus agentes não desautoriza a condenação"48

Tal súmula tem grande impacto quando se trata do crime de tráfico de drogas, visto que é um crime sem vítimas e pelo padrão (não)investigativo perpetrado pelas agências policiais. $\mathrm{O}$ modelo baseado no patrulhamento territorial continua sendo a lógica do sistema penal.

Assim, os depoimentos dos agentes de segurança são, muitas vezes, a única fonte probatória em processos desse tipo. Os altos números de prisão em flagrante, sem qualquer investigação prévia demonstra isso.

Em pesquisa realizada pelo Desembargador do Tribunal de Justiça do Estado de São Paulo, Marcelo Semer, que levou em considerações 800 sentenças, em 8 estados diferentes, constatou que cerca de $88,75 \%$ dos inquéritos tem início com a prisão em flagrante do acusado pelo crime de Tráfico de drogas. ${ }^{49}$

Ademais, outros dados colhidos nessa mesma pesquisa dão conta que em $63 \%$ dos processos a apreensão da droga ocorreu em via pública, superando, segundo o autor, em quase dois terços referente a apreensões ocorridas no interior de residências. ${ }^{50} \mathrm{Em}$ suas palavras:

O volume de droga apreendido na via pública, em quase dois terços dos processos que originaram as sentenças, corresponde inteiramente aos números anteriormente oferecidos, em especial o alto índice de prisão em flagrante sem investigação prévia, a presença expressiva da polícia militar na autuação e, com ela, forte marca do patrulhamento ${ }^{51}$ (grifos pessoais)

\footnotetext{
${ }^{48}$ Súmula da Jurisprudência Predominante (Art. 122 RI) no 2002.146.00001 (Enunciado Criminal ${ }^{\circ}$ 02, do TJRJ) - Julgamento em 04/08/2003 - Votação: unânime - Relator: Des. J. C. Murta Ribeiro Registro de Acórdão em 05/03/2004 - fls. 565/572.

${ }^{49}$ SEMER, M. Sentenciando o tráfico: o papel dos juízes no grande encarceramento. $1^{\text {a }}$. ed. São Paulo: Tirant, 2019. 340 p. página 158

${ }^{50}$ SEMER, M. Sentenciando o tráfico: o papel dos juízes no grande encarceramento. $1^{\mathrm{a}}$. ed. São Paulo: Tirant, 2019. página 163

${ }^{51}$ SEMER, M. Sentenciando o tráfico: o papel dos juízes no grande encarceramento. $1^{\text {a }}$. ed. São Paulo: Tirant, 2019. página 163
} 
Por fim, das drogas apreendidas no interior das residências poucas decorreram da expedição de mandados judiciais (cerca de 16\%) ${ }^{52}$. Os agentes policiais se utilizam das mais diversas justificativas em seus depoimentos judiciais para o descumprimento ao direito a inviolabilidade do lar, sendo, muitas vezes, aceitas pelo poder judiciário. Algo chocante apurado no conjunto de sentenças pesquisado pelo autor, é a ausência de qualquer sentença que considere a ilicitude da prova apresentada pela acusação, mesmo com a pequena parcela de regulação judicial das chamadas incursões policiais.

O que se pode constatar, relacionando a súmula editada pelo Tribunal de Justiça do Rio de Janeiro com a pesquisa apresentada, é um poder desmedido das agências policiais ao se relacionarem com este tipo de delito. Um dos resultados é o papel figurativo do magistrado inserido nesse contexto de guerra.

Revela-se, assim, a lógica do sistema penal, em especial por parte do poder judiciário, de tolerância frente aos abusos e supressão de direitos em prol do combate a esse mal social reunido na figura do traficante de drogas. Esse raciocínio não pode ser analisado como um evento isolado pois possui profundas raízes históricas.

\subsection{2 - Das Raízes autoritárias e o Mito da imagem do traficante.}

Conhecer o passado autoritário do Brasil é elemento chave para a compreensão do avanço desse Estado Policial sem grandes reações sociais relevantes. Nas palavras de Marcelo Semer:

Banhado pela exploração colonial, disciplinado por uma legislação absolutista, coberto por uma longeva e abrangente escravidão, salpicado de períodos ditatoriais mesmo após a proclamação da república. Sufocando movimentos e revoltas populares e mergulhando em conciliações oligárquicas que evitaram tanto quando possível rupturas consideráveis. Não se vive um passado deste sem marcas; se toda a história

\footnotetext{
${ }^{52}$ SEMER, M. Sentenciando o tráfico: o papel dos juízes no grande encarceramento. $1^{\text {a }}$. ed. São Paulo: Tirant, 2019. 340 p. página 166
} 
do Brasil emerge para a consagração das permanências, não há legado mais persistente nas estruturas do poder na própria sociedade do que o autoritarismo ${ }^{53}$ (grifos pessoais)

Exemplo disso pode ser percebido na transição democrática mais recente vivida no país. A Constituição Federal, promulgada em 1988, conhecida como a "Constituição Cidadã" estabeleceu diversos direitos, antes negados pelo Poder Público, possuindo um inegável caráter progressista. Apesar desse notório avanço, o modelo de políticas públicas voltadas à segurança não sofreu grandes alterações nessa transição, que resultou na absorção de elementos de origem autoritária.

O modelo repressivo e a organização militar da polícia ostensiva evidenciam isso. Os moldes voltados ao patrulhamento, desprezando investigação, bem como a obscuridade e rigidez hierárquica decorrente da estrutura militar, são problemas não resolvidos pela constituinte.

O R.O.T.A. (Rondas Ostensivas Tobias Aguiar) exemplifica tal questão, principalmente no que tange o combate do crime organizado, muito conhecida pelos confrontos com o PCC. Sobre essas unidades de operação da Polícia Militar destaco o trecho do livro "A Guerra - A Ascensão do Pcc e O Mundo do Crime No Brasil":

As Rondas Ostensivas Tobias De Aguiar (Rota), criadas em outubro de 1970 para reprimir as ações guerrilheiras, depois se tornariam o terror das quebradas. A disposição para o combate e a letalidade elevada eram suas marcas principais. Da época em que foi criada até novembro de 1980, a Rota, uma unidade com 720 homens, matou 110 pessoas. A situação se agravaria ao longo dos anos de 1980, quando o medo e a sensação de insegurança aumentaram, a Rota seguiria em combate. DE janeiro a setembro de 1981, em nove meses, a Rota mataria 129 pessoas, mais do que todos os mortos em sua primeira década de existência. ${ }^{54}$

\footnotetext{
${ }^{53}$ SEMER, M. Sentenciando o tráfico: o papel dos juízes no grande encarceramento. $1^{\mathrm{a}}$. ed. São Paulo: Tirant, 2019. 340 p. página 127

${ }^{54}$ MANSO, B. P.; DIAS, C. N. A GUERRA: A ASCENSÃO DO PCC E O MUNDO DO CRIME

NO BRASIL. São Paulo : Todavia, 2018.página 108
} 
A redemocratização, oficializada com a Constituição, não só, não reduziu esse cenário, como agravou o mesmo.

Mesmo depois da volta de governos democráticos e da Constituição de 1988, que criou controles para combates os excessos oficiais, essa estratégia de guerra contra o crime nos bairros pobres para proteger os locais mais urbanizados e ricos continuou a estimular a violência e os homicídios policiais. Entre 1981 e 2005, as operações da PM em São Paulo produziram a morte de 14.216 civis, uma média de 592 pessoas por ano. A absoluta maioria dos mortos morava nas periferias pobres de São Paulo. ${ }^{55}$

Todas essas políticas repressivas e abusos cometidos pelo poder públicos são tolerados por parte considerável da sociedade pois esses instrumentos são supostamente sempre utilizados contra um inimigo, este ser que deve ser temido e derrotado a qualquer custo.

Contudo, o estereótipo do traficante como criminoso organizado, bemsucedido, armado e perigoso, construído no imaginário social, não parece encontrar fundamento na realidade cotidiana.

Orlando Zaccone desmitifica tal generalização a partir de sua experiência como Delegado de Polícia:

Os criminosos autuados e presos pela conduta descrita como tráfico de drogas são constituídos por homens e mulheres extremamente pobres, com baixa escolaridade e, na grande maioria dos casos, detidos com drogas sem portar nenhuma arma. Desprovidos de qualquer 'organização', surgem, rotineiramente, nos distritos policiais, os "narcotraficantes", que superlotam os presídios e casas de detenção. ${ }^{56}$

A pesquisa realizada na obra "sentenciando o tráfico" também traz uma luz à essa realidade apresentando dados. Do levantamento realizado pelo Juiz de direito, em somente $21.88 \%$ dos casos houve a acusação de associação em

\footnotetext{
${ }^{55}$ MANSO, B. P.; DIAS, C. N. A GUERRA: A ASCENSÃO DO PCC E O MUNDO DO CRIME NO BRASIL. São Paulo : Todavia, 2018.página 109

${ }^{56}$ D'ELIA FILHO, O. Z. Acionistas do nada: quem são os traficantes de droga. $3^{\text {a }}$. ed. Rio de Janeiro: Revan, 2007. 140 p. páginas 11-12
} 
conexão com os crimes de tráfico de drogas. Ademais, em somente $11.25 \%$ dos processos houve conexão com crimes previstos no Estatuto do desarmamento. ${ }^{57}$

A primariedade e o percentual de coautoria são outros pontos que merecem ser destacados da obra. Dos 800 processos analisados pelo autor, $69.58 \%$ deles tinham no polo passivo um réu primário e em $72 \%$ dos casos tratavam de um só réu. ${ }^{58}$

É notório o abismo entre o que se busca com os discursos penais que viabilizam tais instrumentos repressivos e a realidade apresentada. Apesar do Estado fundamentar a implementação de políticas visando o combate ao crime organizado, o que se percebe na prática é a seletividade penal atuando sobre os mais vulneráveis.

\subsection{3 - Do racismo aplicado na política de drogas.}

Por fim, no tocante à realidade brasileira, um último ponto merece destaque nessa arquitetura repressiva do contexto de combate às drogas, 0 recorte racial. Necessário destacar que o Brasil foi um dos últimos países do mundo a abolir a escravidão, tendo essa política racista perdurado do ano de 1550 até 1888 . Esse período lançou marcas profundas na sociedade até os dias de hoje, a vulnerabilidade penal no Brasil é um recorte étnico/racista.

Ana Luiza Pinheiro Flauzina define racismo:

Assim, tomamos o racismo como uma doutrina, uma ideologia ou um sistema sobre que se apoia determinado segmento populacional considerado como racialmente superior, a fim de conduzir, subjugar um outro tido como inferior. Além de todas as características presentes na definição, sinalizamos expressamente para o caráter desumanizador inscrito na concepção de racismo. Em última instância, o racismo serve

\footnotetext{
${ }^{57}$ SEMER, M. Sentenciando o tráfico: o papel dos juízes no grande encarceramento. $1^{\mathrm{a}}$. ed. São Paulo: Tirant, 2019. 340 p. página 171

${ }^{58}$ SEMER, M. Sentenciando o tráfico: o papel dos juízes no grande encarceramento. $1^{\text {a }}$. ed. São Paulo: Tirant, 2019. 340 p. página 157
} 
como forma de catalogação dos indivíduos, afastando-os ou aproximando-os do sentido de humanidade de acordo com suas características raciais. ${ }^{59}$

A diferença da mídia no trato entre brancos e negros quando se trata de casos envolvendo tráfico de entorpecentes é visível. Enquanto os negros recebem imediatamente a etiqueta de "traficante", os brancos são tratados muitas vezes pela sua origem ou profissão.

Os dados do sistema penal também não são diferentes. Uma reportagem publicada em maio de 2019 pela "Agência Pública", que teve como objeto de pesquisa quatro mil sentenças referentes ao crime de tráfico de drogas, todas elas do ano de 2017, demonstrou que negros são proporcionalmente mais condenados que brancos, representando um percentual menor de drogas apreendidas. ${ }^{60}$

Ante o exposto, o que se pode notar é que, dentro da estrutura seletiva do sistema penal, o poder punitivo encontra na figura do traficante, o inimigo perfeito para justificar políticas repressivas e o inquestionável avanço do Estado de Polícia. No Brasil, o recorte social e étnico dos números de encarceramento demonstram a verdadeira finalidade da guerra às drogas.

Os políticos que se valem dessa narrativa e tem como prioridade um modelo de segurança ostensivo ganham cada vez mais popularidade. Ignora-se o óbvio aumento do estado penal em função do sentimento de medo e insegurança, tão presentes em nossa sociedade. $\mathrm{Na}$ atual quadra histórica, os discursos assumem uma natureza extremista, sendo aceitos com certa naturalidade e apoiados por uma parcela da população.

\footnotetext{
${ }^{59}$ FLAUZINA, A. L. P. Corpo Negro Caído no chão: O Sistema Penal e o Projeto Genocida do Estado brasileiro. Brasília: [s.n.], 2006. página 12

${ }^{60}$ DOMENICI, T.; BARCELOS, I. Negros são mais condenados por tráfico e com menos drogas em São Paulo. Agência Pública. Disponivel em: $<$ https://apublica.org/2019/05/negros-sao-maiscondenados-por-trafico-e-com-menos-drogas-em-sao-paulo/>.
} 
Esse sentimento punitivista, presente(cultivado) na sociedade brasileira frente ao mal das organizações criminosas deixou de ser uma exclusividade das drogas. $\mathrm{O}$ combate à corrupção ganhou grande notoriedade e apoio no tecido social, ficando conhecida como Operação Lava Jato. Como será exposto, essa perseguição se valeu do discurso contra o crime organizado de colarinho branco para operar de maneira seletiva visando, principalmente, um grupo político específico. 


\section{Capítulo 4. 0 inimigo no combate à corrupção}

Intitulada de "maior operação de combate à corrupção da história do Brasil", a Lava Jato, sem dúvida, alterou os rumos jurídicos, políticos e sociais da nação. Essa investigação da Polícia Federal iniciou no Paraná no ano de 2014 e teve como alvo um suposto esquema envolvendo a Petrobrás, empreiteiras, operadores financeiros e políticos de diferentes partidos.

Com uma intensa cobertura e apoio da grande mídia a Lava Jato se tornou tema rotineiro no cotidiano social, sendo debatido em meio a todos os círculos sociais. Além do claro interesse das grandes corporações de comunicação, o discurso de combate contra à corrupção encontra grande apoio social por motivos óbvios.

Todo esse suporte acrítico fornecido pela mídia dissimulou diversos excessos cometidos nas diversas fases da mega investigação. O enredo construído em torno dos delitos investigados introduziu no imaginário social um mega esquema de corrupção perpetuado por uma organização criminosa, que tinha como líder o ex-presidente Luiz Inácio da Silva, alvo de diversos processos. O retrato do corrupto, o grande inimigo da nação, se sintetizou na figura de Lula.

Contrapondo-se há tudo que representa esse hostil à sociedade, em uma espécie de "messianismo judicial", surge a figura do juiz-herói, papel esse cumprido por Sérgio Moro nessa narrativa maniqueísta. O então magistrado da $13^{a}$ Vara Criminal de Curitiba de perfil midiático conquistou enorme fama pelo rigor com que julgava os acusados. Essa popularidade acobertou abusos e irregularidades processuais ao longo da investigação.

Diversos diálogos publicados inicialmente pelo site de notícias Intercept Brasil, em uma série de reportagens denominadas de "Vaza Jato", revelaram a verdadeira estrutura por detrás das investigações. As conversas revelaram o 
desrespeito ao sistema acusatório, pois ficou claro a participação do juiz na produção probatória.

Garantias constitucionais como direito à privacidade, presunção de inocência e a imparcialidade do juízo foram afastadas em prol dessa outra guerra travada no sistema penal.

Sobre esse tema elucida Rubens Casara "Direitos e garantias fundamentais, vistos como obstáculos aos objetivos repressivos, moralizantes e políticos da Operação Lava Jato, teriam sido afastados"61

Assim, seguindo os preceitos do direito penal do inimigo, a Lava Jato atua seletivamente, ignorando regras tão caras à doutrina penalista clássica, levando em conta o réu. A seguir será realizado uma breve análise sobre o instituto colaboração premiada pela operação e ao final do capítulo será analisado o processo de construção da figura do inimigo político.

\section{1 - A colaboração premiada e o direito penal do inimigo.}

Alvo de críticas por parte da doutrina penalista, a colaboração premiada passou a fazer parte da realidade do processo penal brasileiro por conta da Operação Lava Jato. Prevista na Lei das Organizações Criminosas foi, sem dúvida, o principal instrumento utilizado pela Força Tarefa.

De início, demonstra-se relevante destacar que a expressão escolhida pelo legislador na Lei 12.850/2013 para nomear o instituto não está correta conforme ensina Guilherme Nucci. Contudo, por ter sido o termo previsto na norma, ambas as expressões ("colaboração" e "delação") serão utilizadas no presente artigo.

\footnotetext{
${ }^{61}$ CASARA, R. R. Estado pós-democrático: neo-obscurantismo e gestão dos indesejáveis. Rio de Janeiro: Civilização Brasileira, 2018. 240 p. página 200
} 
Neste sentido, afirma Nucci:

Embora a lei utilize a expressão colaboração premiada, cuida-se, na verdade, da delação premiada. O instituto, tal como disposto em lei, não se destina a qualquer espécie de cooperação de investigado ou acusado, mas àquela na qual se descobrem dados desconhecidos quanto à autoria ou materialidade da infração penal. Por isso, trata-se de autêntica delação, no perfeito sentido de acusar ou denunciar alguém vulgarmente, o dedurismo. ${ }^{62}$ (grifos pessoais)

Em linhas históricas gerais, a ideia de delação premiada tem raízes na Idade Média, mais especificamente, na Inquisição (séculos XII-XIV). Período esse conhecido pela perseguição realizada pela Igreja católica contra praticantes de religiões distintas, rotulados como "Hereges".

Apesar desse passado, as influências modernas recepcionados pela legislação nacional acerca do tema, podem ser encontradas no plea bargain, presente no sistema common law estadunidense, caracterizado pelo acordo entre a acusação e o polo passivo da ação penal afim de evitar o julgamento. Tal medida possui caráter eficientista e tem como finalidade reduzir o número de julgamentos no âmbito penal. Dados evidenciam que, nos EUA, cerca de 95\% dos processos criminais são encerrados por acordos antes do julgamento. ${ }^{63}$

Importante destacar que nas transações norte-americanas, existe a vedação da participação do Juiz/Corte nas discussões dos acordos, devendo ser realizados somente entre as partes. Ao magistrado, cabe analisar as condições do acordo, podendo aceitá-lo ou rejeitá-lo. ${ }^{64}$ A Legislação interna brasileira adotou essa política $\left(12.850\right.$, artigo $4^{\circ}, \S \S 6^{\circ}$ e $\left.7^{\circ}\right)$.

\footnotetext{
${ }^{62}$ NUCCI, G. D. S. Organização Criminosa. 2a . ed. Rio de Janeiro: Forense, 2015. página 39

${ }^{63}$ ACORDOS na justiça criminal dos EUA chegam a 95\%. Estado de Minas, Minas Gerais, 30 jan. $2019 . \quad$ Disponivel em: $<$ https://www.em.com.br/app/noticia/politica/2019/01/30/interna_politica,1026086/acordos-na-justicacriminal-dos-eua-chegam-a-95.shtml $>$.

${ }^{64}$ Federal Crimes of Criminal Procedure, 2016. Rule 11. (c)
} 
Outra grande influência para o direito pátrio no que tange à colaboração pode ser encontrado na Itália. A colaboração premiada começou a ser adotada nos anos de 1970 pelo país com intuito de combater terroristas, contudo somente ganhará notoriedade a partir da operazione mani pulite, quando passou a usar esse instrumento para o combate à corrupção durante a década 1990, esta operação que é, publicamente, a grande inspiração do ex-juiz Sérgio Moro.

A operação italiana, deflagrada entre os anos de 1992 a 1994, também utilizou o instituto da delação premiada como principal meio de obtenção de provas. Essa mega investigação resultou na extinção de uma série de partidos, e contribuiu para a ascensão do político Silvio Berlusconi. A Mani Pulite foi alvo de críticas de diversos juristas, principalmente por partes adeptos do Garantismo Penal, à época, recém teorizado pelo italiano Luigi Ferrajioli, de inequívoca raiz iluminista. ${ }^{65}$

No que tange o direito brasileiro, este instituto não pode ser considerado novidade, visto sua previsão desde as Ordenações Filipinas (1603-1830), internalizada na legislação interna, para os crimes chamados de "lesamajestade", diversas outras normas posteriores também versaram sobre o tema. Apesar desse histórico legislativo, a delação premiada só será realmente difundida a partir da Lava Jato.

Dentre os institutos que mais se destacaram nessa cruzada brasileira contra a corrupção, a Colaboração premiada é, sem dúvida, o grande pilar de sustentação da Lava Jato. Previsto na Lei de Organizações criminosas, o referido instituto é o principal instrumento de meio de produção probatória nos processos da Lava Jato.

O artigo $4^{\circ}$ da Lei 12.850/2013, regula a colaboração da seguinte forma:

\footnotetext{
${ }^{65}$ D’IPPOLITO, F.; FIGUEIREDO, M. Mani Pulite Operação Mãos Limpas - 25 anos depois.

Migalhas, novembro 2017. Disponivel em:

$<$ https://www.migalhas.com.br/dePeso/16,MI269664,51045-

Mani+Pulite+Operacao+Maos+Limpas+25+anos+depois $>$.
} 
Art. $4^{\circ}$. O juiz poderá, a requerimento das partes, conceder o perdão judicial, reduzir em até $2 / 3$ (dois terços) a pena privativa de liberdade ou substituí-la por restritiva de direitos daquele que tenha colaborado efetiva e voluntariamente com a investigação e com o processo criminal, desde que dessa colaboração advenha um ou mais dos seguintes resultados:

I - a identificação dos demais coautores e partícipes da organização criminosa e das infrações penais por eles praticadas;

II - a revelação da estrutura hierárquica e da divisão de tarefas da organização criminosa;

III - a prevenção de infrações penais decorrentes das atividades da organização criminosa;

IV - a recuperação total ou parcial do produto ou do proveito das infrações penais praticadas pela organização criminosa;

$\mathrm{V}$ - a localização de eventual vítima com a sua integridade física preservada.

Oriunda da lógica eficientista da justiça negociada e de questionável recepção constitucional, a aplicação desses acordos no âmbito da Lava Jato desencadeou um verdadeiro efeito dominó de colaborações. Muitas das narrativas apresentadas pelos investigados careciam de outro suporte probatório além de suas versões.

Importante a lição de NUCCI sobre a valoração da delação pode ser destacada no trecho abaixo:

O valor da colaboração premiada é relativo, pois se trata de uma declaração de interessado (investigado ou acusado) na persecução penal, que pretende auferir um benefício, prejudicando terceiros. Embora assuma a prática do crime, o objetivo não é a pura autoincriminação, mas a consecução de um prêmio. Diante disso, é inviável lastrear a condenação de alguém baseado unicamente numa delação. É fundamental que esteja acompanhada de outras provas, nos mesmos moldes em que se considera o valor da confissão. Note-se o disposto pelo art. 4. ${ }^{\circ}, \S 16$, da Lei 12.850/2013: "Nenhuma sentença condenatória será proferida com fundamento apenas nas declarações de agente colaborador. ${ }^{66}$ (Grifos pessoais)

A utilização do instituto da colaboração premiada pela Lava Jato demonstra elementos passiveis de críticas, o envolvimento do Poder Judiciário

\footnotetext{
${ }^{66}$ NUCCI, G. D. S. Organização Criminosa. 2a . ed. Rio de Janeiro: Forense, 2015.páginas 40-41
} 
na elaboração dos acordos e as divulgações seletivas de depoimentos serão abordados no presente trabalho. Nesse sentido, Rubens Casara Elucida:

A delação premiada, que o legislador passou a chamar de "colaboração premiada" para encobrir o desvio ético inerente a toda e qualquer delação, aparece na cena pósdemocrática como um instrumento capaz de potencializar a eficácia punitiva do Estado e, ao mesmo tempo, fornece novos ingredientes ao processo penal transformado em espetáculo. ${ }^{67}$

Conforme já dito, os $\S \S 6^{\circ}$ e $7^{\circ}$ do artigo $4^{\circ}$ da Lei de Organizações Criminosas descrevem o papel do juiz no que tange o acordo Colaboração premiada, possuindo as seguintes redações:

Art. $4^{\circ}$.

...

$\S 6^{\circ}$. O juiz não participará das negociações realizadas entre as partes para a formalização do acordo de colaboração, que ocorrerá entre o delegado de polícia, o investigado e o defensor, com manifestação do Ministério Público, ou, conforme o caso, entre o Ministério Público e o investigado ou acusado e seu defensor.

$\S 7^{\circ}$. Realizado o acordo na forma do $\S 6^{\circ}$, o respectivo termo, acompanhado das declarações do colaborador e de cópia da investigação, será remetido ao juiz para homologação, o qual deverá verificar sua regularidade, legalidade e voluntariedade, podendo para este fim, sigilosamente, ouvir o colaborador, na presença de seu defensor." (Lei 12850/2013)

Apesar da clareza das regras legais estabelecidas, que seguem minimamente o norte do Estado de Direito estabelecendo a imparcialidade do Poder Judiciário, a realidade prática da Lava Jato demonstrou a violação desses preceitos, bem como o sistema acusatório. Em uma das reportagens da série "Vaza Jato", os diálogos divulgados demonstraram, inequivocamente, a verdadeira face inquisitória do então juiz da $13^{\text {a }}$ Vara Criminal, Sérgio Moro.

Em reportagem feita em parceria do site Intercept Brasil e o jornal Folha de São Paulo, publicada no dia 18 de julho de 2019, diálogos realizados entre Procuradores da Operação demonstraram que Moro impôs condições à delação referentes à empreiteira Camargo Correia. Ademais, ficou claro que os

\footnotetext{
${ }^{67}$ CASARA, R. R. Estado pós-democrático: neo-obscurantismo e gestão dos indesejáveis. Rio de Janeiro: Civilização Brasileira, 2018. 240 p. página 202
} 
Procuradores se consultavam com o juiz Federal para tratar de termos de negociações em andamento. ${ }^{68}$

A interferência do magistrado na produção probatória se mostrou tão corriqueira que era vista com naturalidade pelos membros do Ministério Público Federal. Os diálogos demonstraram uma relação íntima entre acusação e o julgador, bem como a completa violação do sistema acusatório.

A imparcialidade do juiz é condição de validade do processo, sendo o grande pilar do sistema acusatório, do qual o Brasil é adepto. Aury Lopes Jr. esclarece a função do juiz no Processo penal no trecho destacado.

A imparcialidade do órgão jurisdicional é um "princípio supremo do processo" e, como tal, imprescindível para o seu normal desenvolvimento e obtenção do reparto judicial justo. Sobre a base da imparcialidade está estruturado o processo como tipo heterônomo de reparto. ${ }^{69}$

Conforme já dito, essa série de reportagens intituladas "vaza jato" expôs diversas práticas autoritárias ocorridas na Lava Jato, e nesse caso exposto, demonstrou atividades ilegais e de natureza inquisitória praticadas sobre bandeira do combate à corrupção. Frente a esse inimigo de natureza conspiratória, foi necessário a violação da Garantia da Imparcialidade do julgador em um envolvimento direto na produção probatória, manipulando o processo judicial e atuando como o coordenador de fato da Operação.

Outro ponto que toca os abusos conferidos na utilização do instituto da colaboração premiada na Lava Jato está no vazamento para a mídia de depoimentos da delação. Dentre essas divulgações, o testemunho do Palloci no contexto de véspera das eleições presidenciais de 2018, cujo teor prejudicava o

\footnotetext{
${ }^{68}$ BALTHAZAR, R.; BIANCHI, P. Mensagens apontam que Moro interferiu em negociação de delações. Foha de São Paulo, São Paulo, 18 Julho 2019. Disponivel em:

$<$ https://www1.folha.uol.com.br/poder/2019/07/mensagens-apontam-que-moro-interferiu-emnegociacao-de-delacoes.shtml>.

${ }^{69}$ LOPES JR. , A. Direito Processual Penal. 12a . ed. São Paulo: Saraiva, 2015. página 62
} 
ex-presidente Lula, merece destaque. Por essa medida, Sérgio Moro respondeu uma reclamação contra ele, apresentada no Conselho Nacional de Justiça. ${ }^{70}$

O que na época já se mostrou um indício de tentativa de influenciar as eleições, outra reportagem da Vaza Jato demonstrou, inequivocamente, ser esta a real intenção do atual Ministro da Justiça.

Outros diálogos entre os Procuradores da Lava Jato, divulgados pelo jornal Folha de São Paulo, revelaram a insegurança quanto ao suporte probatório coletado que corroborasse com a delação do ex ministro da fazenda do governo Lula. Mesmo duvidando das provas coletadas nesse acordo, Sergio Moro divulgou tais depoimentos, em uma clara tentativa de prejudicar o Partido dos Trabalhadores nas eleições presidenciais de 2018. ${ }^{71}$

Rubens Casara também aponta para o aspecto da espetacularização na relação entre as delações e seus vazamentos.

[...] a delação premiada e o vazamento do seu conteúdo acabaram por ser utilizados no decorrer da Operação Lava Jato com a mesma lógica dos efeitos especiais em um filme hollywoodiano, ou seja, como uma estratégia para resgatar a atenção do público para o espetáculo e agradar a audiência. ${ }^{72}$

Ademais, é possível notar o exagero no tocante à utilização dessa poderosa ferramenta legal pela Operação Lava Jato. Levantamento feito pelo JOTA, evidencia o uso excessivo da delação nos processos do âmbito da forçatarefa, o portal de notícias jurídico informou, em abril de 2019, que dos 163

\footnotetext{
${ }^{70}$ COELHO, G. CNJ pede explicações a Moro sobre divulgação da delação de Palocci. Consultor Jurídico, 4 outubro 2018. Disponivel em: <https://www.conjur.com.br/2018-out-04/cnj-explicacoesmoro-divulgacao-delacao-palocci>.

${ }^{71}$ BALTHAZAR, R.; MORO MARTINS, R. Moro achava fraca delação de Palocci que divulgou às vésperas de eleição, sugerem mensagens. Folha de São Paulo, São Paulo, 29 Julho 2019. Disponivel em: <https://www1.folha.uol.com.br/poder/2019/07/moro-achava-fraca-delacao-de-palocci-quedivulgou-as-vesperas-de-eleicao-sugerem-mensagens.shtml>.

${ }^{72}$ CASARA, R. R. Estado pós-democrático: neo-obscurantismo e gestão dos indesejáveis. Rio de Janeiro: Civilização Brasileira, 2018. 240 p. página 202
} 
condenados em primeira instância pela Lava Jato, 67 deles realizaram acordo, contabilizados os realizados no Supremo Tribunal Federal, representando cerca de $41 \%$ dos sentenciados culpados. ${ }^{73}$

Por fim, o último ponto a ser destacado sobre esse instituto é a sua combinação com as prisões, em um claro abuso da força estatal frente aos limites constitucionais. Utilizadas desde o início da operação, esta que teve início a partir da prisão de Youssef $^{74}$, as prisões preventivas tinham um papel fundamental para o prosseguimento das ações penais, visto que serviam como uma espécie de coação com a finalidade de constranger ao investigado a realizar o acordo de colaboração premiada.

O Ministro Gilmar Mendes, em sessão realizada em outubro de 2019 no Supremo Tribunal Federal, em ação que discutia a ordem das alegações penais dentro do processo penal efetuou duras críticas ao modo de atuação da Força Tarefa. O Ministro do STF definiu o período da Lava Jato como de "trevas no processo penal"75 e classificou a utilização da prisão como "instrumento de tortura".

Rubens R. R. Casara, em seu livro "Estado pós-democrático: neoobscurantismo e gestão dos indesejáveis", discorre sobre essa relação entre a prisão e delação, comenta:

Também não são poucos os relatos de prisões no curso das investigações ou dos processos relacionados à Lava Jato que teriam sido decretadas sem a presença dos requisitos legais e com o objetivo aparente de forçar os investigados a fazerem 'delações premiadas'. Segundo essa tese, que encontra eco em diversos pareceres de

\footnotetext{
${ }^{73}$ PÁDUA, L. Dos 163 condenados na Lava Jato de Curitiba, 40\% são delatores. JOTA, São Paulo, Abril 2019. Disponivel em: $<$ https://www.jota.info/justica/lava-jato-curitiba-condenados-delatores15042019>.

${ }^{74}$ BRANDT, R. Delação de Alberto Youssef desencadeou a Lava Jato. Estadão, São Paulo, 23 Setembro 2018. Disponivel em: $<$ https://politica.estadao.com.br/noticias/geral,delacao-de-albertoyoussef-desencadeou-a-lava-jato,70002516081>.

75 "LAVA jato" usava prisão provisória como elemento de tortura, diz Gilmar, 2 Outubro 2019. Disponivel em: $<$ https://www.conjur.com.br/2019-out-02/lava-jato-usava-prisao-provisoria-elementotortura-gilmar $>$.
} 
juristas, prisões foram utilizadas como forma de coagir pessoas a apresentarem versões que interessavam aos órgãos encarregados da persecução penal. ${ }^{76}$

A partir da análise da delação premiada e do seu manejo pela operação Lava Jato, ficou demonstrada a seletividade penal no que tange o combate à corrupção. Nesse sentido, a série de reportagens intituladas "Vaza Jato" em muito contribuiu para revelar a verdadeira Inquisição por detrás desses processos penais. Na melhor lógica teorizada por Jakobs, o que se viu na prática foi o afastamento de garantias fundamentais em função do réu. Inimigo esse que será objeto de análise a seguir.

\section{2 - A construção do Inimigo político (Ação Penal 470, Operação Lava Jato e Espetacularização).}

A justificativa para implementação e aplicação dessas novas medidas repressivas, inerentes ao crescimento do Estado Policial se tornou o combate à corrupção, que recaiu, principalmente sobre filiados ao Partido dos Trabalhadores e seus aliados. Este partido político ficou à frente do Poder Executivo entre os anos de 2003 a 2016, elegendo dois governantes nesse período (Lula e Dilma Roussef) e está no centro do processo de formação do inimigo político. Importante destacar que a Lava Jato não criou a figura do hostil, mas foi essencial para seu desenvolvimento no tecido social e no âmbito judicial.

A Operação Lava Jato não foi o primeiro "escândalo" de corrupção enfrentado pelo PT. A Ação Penal 470, popularmente conhecida como mensalão, teve início no ano de 2007 e tramitou no STF e, assim como a Lava Jato, foi um processo cercado de cobertura midiática. Nesse momento dá-se início ao que Rubens Casara chama de "espetacularização do processo penal”.

\footnotetext{
${ }^{76}$ CASARA, R. R. Estado pós-democrático: neo-obscurantismo e gestão dos indesejáveis. Rio de Janeiro: Civilização Brasileira, 2018.página 201
} 
O julgamento da Ação Penal 470 pelo Supremo Tribunal Federal, caso penal que ganhou destaques nos meios de comunicação/ de massa e ficou conhecido como Mensalão - nome que se origina da versão de que o governo do Partido dos Trabalhadores pagava mensalmente a parlamentares de diversos partidos em troca de apoio, o que não foi demonstrado ao fim das investigações, foi um marco no processo de transformação do processo penal em espetáculo, em que a solução justa do caso penal é substituída pelo "desejo de audiência. ${ }^{77}$ (grifos pessoais)

Esse processo teorizado no país pelo juiz de direito configura elemento chave para essa formação do inimigo político. O espetáculo, como uma construção social se caracteriza pela mediação através de sensações e não pela razão. Em nossa sociedade o espetáculo age como regulador das expectativas sociais, ao passo que quem consome esse espetáculo também o influencia, esses consumidores, assim, realizam uma dupla função de atuar e assistir. ${ }^{78}$

Nesse enredo espetaculoso, o processo penal se torna objeto de consumo e, como consequência, se afastando de sua finalidade originária de racionalização e contenção do poder punitivo para servir de entretenimento social. ${ }^{79}$

No 'processo penal do espetáculo', os valores típicos da jurisdição penal de viés liberal ('verdade' e 'liberdade') são abandonados e substituídos por um enredo que aposta na prisão e no sofrimento imposto a investigados e réus como forma de manter a atenção e agradar ao público; isso faz com que a atividade processual cada vez mais limite-se a confirmar a hipótese acusatória. ${ }^{80}$

Dessa forma nota-se o avanço da "indústria cultural" no direito, envolvendo-o na sua lógica maniqueísta. A personificação dos autores envolvidos nesses processos midiáticos evidencia isso, a representação de um pensamento binário entre o "bem" e o "mal", tão utilizado em obras de ficção, é

\footnotetext{
${ }^{77}$ CASARA, R. R. Estado pós-democrático: neo-obscurantismo e gestão dos indesejáveis. Rio de Janeiro: Civilização Brasileira, 2018. página 192

${ }^{78}$ CASARA, R. R. Estado pós-democrático: neo-obscurantismo e gestão dos indesejáveis. Rio de Janeiro: Civilização Brasileira, 2018.página 159

${ }^{79}$ CASARA, R. R. Estado pós-democrático: neo-obscurantismo e gestão dos indesejáveis. Rio de Janeiro: Civilização Brasileira, 2018. página 160

${ }^{80}$ CASARA, R. R. Estado pós-democrático: neo-obscurantismo e gestão dos indesejáveis. Rio de Janeiro: Civilização Brasileira, 2018. página 160
} 
absorvida no processo penal trazendo graves consequências para o Estado de Direito.

A relação entre o processo penal e a construção desse inimigo político no Brasil encontra o primeiro marco na Ação Penal 470 (o Mensalão). Em breve síntese, essa ação foi instaurada perante o Supremo Tribunal Federal em novembro de 2007 e em sua denúncia contava com 40 indivíduos, entre parlamentares, empresários e funcionários de empresas públicas e privadas acusados de compor uma Organização Criminosa voltada para um esquema de corrupção envolvendo favorecimentos políticos ao Partido dos Trabalhadores.

Nesse processo espetaculoso perpetraram-se diversos abusos cometidos pela Justiça Brasileira sendo certo que estes foram acobertados pela narrativa cinematográfica que cercava o caso. A título ilustrativo, alguns exemplos desses excessos ocorridos no Mensalão podem ser elencados.

Nessa ação, o que se viu foi um desvio no que tange as regras de competência, visto que o Supremo Tribunal Federal julgou todos os acusados, mesmo os não abarcados pelo foro por prerrogativa de função. Essa regra de competência, popularmente conhecida como "foro privilegiado", divide a doutrina pois reduz o acesso do acusado ao sistema recursal. Essa opção interpretativa feita pelo STF demonstra uma certa escolha jurisdicional por parte da Suprema Corte em julgar o Mensalão. ${ }^{81}$

A opção por julgar esse processo à frente de outros casos semelhantes e mais antigos é outra prova da seletividade perpetrada nesse processo. ${ }^{82}$

Por fim, outra atipicidade pode ser localizada na fase de admissibilidade da acusação, visto que alguns ministros presentes na sessão não se limitaram à análise dos indícios de autoria e materialidade e adentraram ao mérito,

\footnotetext{
${ }^{81}$ CASARA, R. R. Estado pós-democrático: neo-obscurantismo e gestão dos indesejáveis. Rio de Janeiro: Civilização Brasileira, 2018. página 195

${ }^{82}$ CASARA, R. R. Estado pós-democrático: neo-obscurantismo e gestão dos indesejáveis. Rio de Janeiro: Civilização Brasileira, 2018. 240 p.
} 
antecipando seu juízo condenatório. ${ }^{83}$ Tais exemplos demonstram algumas das arbitrariedades que circundaram esse processo.

Com o contexto midiático como plano de fundo do Mensalão, os atores foram personificados e, assim como na Lava Jato, a figura do herói de todo esse enredo é assumida pelo Ministro-Relator da ação, Joaquim Barbosa. Retratado na mídia como o "justiceiro" da sociedade brasileira o ex ministro do STF adquiriu enorme popularidade.

A reportagem publicada no ano de 2012 pelo site "O Globo" demonstra isso:

BRASÍLIA - O mensalão está nas redes sociais - e virou até piada - como forma de manifestar a torcida pela punição aos culpados. $\mathrm{O}$ relator, ministro Joaquim Barbosa, se transformou na personificação de quem levará políticos para a cadeia. Desde que começou o julgamento, circulam na internet mensagens de apoio e defesa ao ministro. São os "memes", imagens distribuídas e compartilhadas pelos usuários que sintetizam uma ideia. Nessas imagens, Barbosa é colocado como herói, justiceiro e exemplo para o país. ${ }^{84}$ (grifos pessoais)

Em contraponto a esse herói togado encontram-se os acusados, condensados e representados pelo Partido dos Trabalhadores. Apesar da Ação Penal 470 não ter tido relação direta com Lula, visto que não foi comprovado seu envolvimento nesse Organização Criminosa, sua imagem, bem como a de todo o partido ficou bastante afetada, principalmente para uma parcela mais abastada da população.

Tudo indica ter sido o Mensalão, a gênese da formação desse inimigo político do cenário atual brasileiro, contudo é na Operação Lava Jato que esse inimigo tomará outras proporções.

Cercado de semelhanças com a Ação Penal 470, a Lava Jato também teve como objeto um suposto esquema de corrupção envolvendo o Partido dos

\footnotetext{
${ }^{83}$ CASARA, R. R. Estado pós-democrático: neo-obscurantismo e gestão dos indesejáveis. Rio de Janeiro: Civilização Brasileira, 2018. página 194

${ }^{84}$ PIERRY, F. Joaquim Barbosa é o "justiceiro" nas redes sociais. O Globo, Brasília, 07 Setembro 2012. Disponivel em: <https://oglobo.globo.com/brasil/joaquim-barbosa-o-justiceiro-nas-redessociais-6024965>.
} 
Trabalhadores e contou com extensa cobertura midiática. Nesse contexto de espetacularização, não mais inédito na história brasileira, a Justiça também irá operar de forma seletiva e arbitrária se utilizando do discurso de combate contra a corrupção.

Há relatos de violações da imparcialidade jurisdicional, das regras de competência, inviolabilidade de comunicações telefônicas (alvo de vazamentos seletivos com impactos políticos), vedação à prova ilícita, da cadeia de custódia probatória, conduções coercitivas abusivas e utilização de prisões para obtenção de delações. ${ }^{85}$

Mais uma vez é importante ressaltar o papel representado pela série de reportagens "Vaza Jato" que colocou luz acerca do modus operandi da operação e demonstrou, de forma cabal, a parcialidade da atuação do então juiz Sergio Moro.

Sobre essa forma de operar é curiosa a ironia demonstrada por Gilmar Mendes ao se referir a Operação de combate a corrupção em entrevista concedida ao "Correio Brasiliense" em agosto de 2019. O ministro do STF afirmou ter sido criado "estado paralelo" no país e classificou os processos como um “jogo de compadres” realizado por uma “organização criminosa para investigar pessoas". ${ }^{86}$

Assim como no caso Mensalão, em uma narrativa desenvolvida pela mídia, surge o salvador da pátria representado na figura de um juiz e mais uma vez encontra o Partido dos Trabalhadores no polo passivo nesse contexto dualista. Contudo, a diferença consiste no fato de Lula será acusado diretamente

\footnotetext{
${ }^{85}$ CASARA, R. R. Estado pós-democrático: neo-obscurantismo e gestão dos indesejáveis. Rio de Janeiro: Civilização Brasileira, 2018. página 201

${ }^{86}$ GILMAR critica Lava-Jato: "Organização criminosa para investigar pessoas". Correio brasiliense, Brasília, 04 Agosto 2019. Disponivel em:

$<$ https://www.correiobraziliense.com.br/app/noticia/politica/2019/08/04/interna_politica,775355/gilma r-mendes-chama-lava-jato-de-organizacao-criminosa-em-entrevista.shtml $>$.
} 
do envolvimento na Organização Criminosa e, agora receberá o rótulo oficial de "inimigo público".

Exemplo disso pode ser destacado na sentença dada por Moro no processo conhecido popularmente como "caso triplex", que tinha o Lula como réu. Entre os parágrafos 800 a 804 da sentença, o então magistrado se utiliza de um enorme esforço interpretativo, não só para ligar o réu com a suposta organização criminosa, como para apontá-lo como o líder de todo esse esquema corrupto. Se valendo, inclusive, de supostas condutas ocorridas no Mensalão com relação a uma falta de reprovação de sua parte.

800. Seria esta talvez uma questão relevante se o ex-Presidente Luiz Inácio Lula da Silva fosse acusado da responsabilidade pelo esquema criminoso que vitimou a Petrobrás por omissão, mas ocorre que a acusação é no sentido de que ele teria dele participado ativamente, inclusive beneficiando-se indiretamente, já que recursos de vantagem indevida teriam sido direcionados ao Partido dos Trabalhadores e a outros partidos de sua base aliada, e também diretamente para enriquecimento pessoal, como consta na parte da denúncia atinente ao apartamento triplex.

801. Parece, aliás, um pouco estranho que, diante da magnitude do esquema criminoso, ilustrado pelo fato da Petrobrás ter reconhecido cerca de seis bilhões de reais em perdas contábeis com corrupção no balanço de 2015, não tivesse o ex-Presidente qualquer conhecimento, máxime porque ele, o esquema criminoso, também teria envolvido utilização de propinas em acertos de corrupção na Petrobrás para financiamento de campanhas eleitorais, inclusive do Partido dos Trabalhadores e pelo qual o exPresidente foi eleito e elegeu sua sucessora.

802. Além disso, chama a atenção a ausência de qualquer juízo de reprovação da parte do ex-Presidente em relação a agentes públicos e políticos que, durante o seu Governo, teriam participado do esquema criminoso que vitimou a Petrobrás.

803. Foi para melhor entender a relação do ex-Presidente com seus subordinados surpreendidos em práticas criminosas que este Juízo realizou no interrogatório da ação penal (evento 885) perguntas a respeito de sua posição em relação ao esquema criminoso denominado de "Mensalão" cuja existência foi reconhecida, com trânsito em julgado, pelo Egrégio Supremo Tribunal Federal, na Ação Penal 470, com condenações criminais contra expoentes do Partido dos Trabalhadores como José Dirceu de Oliveira e Silva, Delúbio Soares de Castro e João Paulo Cunha. Na ocasião, o Juízo chamou a atenção do acusado para sucessivas entrevistas contraditórias por ele concedidas na imprensa sobre o tema, ora afirmando que teria sido "traído por práticas inaceitáveis" , ora afirmando que não havia prova e que a decisão do Supremo Tribunal Federal teria sido política ("o mensalão, o tempo vai se encarregar de provar que o mensalão, você teve $80 \%$ de decisão política e $20 \%$ de decisão jurídica"), mas não obteve esclarecimentos. As várias entrevistas contraditórias concedidas pelo ex-Presidente 
sobre os fatos abrangidos pela Ação Penal 470 encontram-se no evento 724, anexo19, anexo20 e anexo22.

804. Usualmente, se um subordinado pratica um crime com a ignorância do superior, quando o crime é revelado, o comportamento esperado do superior é a reprovação da conduta e a exigência de que malfeito seja punido. Não se verificou essa espécie de comportamento por parte do ex-Presidente, pelo menos nada além de afirmações genéricas de que os culpados deveriam ser punidos, mas sem qualquer designação específica, como se não houvesse culpados cuja responsabilidade já não houvesse sido determinada, como, no caso, aliás, da Ação Penal 470, com trânsito em julgado. Trata se de um indício relevante de conivência em relação ao comportamento criminoso dos subordinados e que pode ser considerado como elemento de prova. ${ }^{87}$

Esse trecho jurisprudencial resume o sentimento punitivista da Lava Jato, que via em Lula seu principal inimigo, se valendo de malabarismos interpretativos sem comprovação probatória, para confirmar a trama desenvolvida pela mídia.

Se, no âmbito jurídico, a Lava Jato teve como resultado a normalização da implementação de instrumentos de repressão e o inequívoco aumento do Estado Penal, também se percebe seus reflexos no âmbito político.

A operação não só reforçou o imaginário social do inimigo político, representado pelo PT e Lula, como também inflamou uma manifestação contrária contra toda a classe política como um todo. A Ascenção de um discurso outsider político ganha popularidade na sociedade, prova disso está no fato que nas eleições de 2018 o parlamento sofreu uma renovação recorde no preenchimento das vagas eleitorais (47,3\% na Câmara dos Deputados ${ }^{88}$ e $87 \%$ no Senado Federal ${ }^{89}$ ).

O Impedimento sofrido pela presidente Dilma Roussef também pode ser apontado como outra consequência política desse processo de demonização. Em

\footnotetext{
${ }^{87} 13^{\mathrm{a}}$ Vara Criminal Federal de Curitiba, Ação Penal n ${ }^{\circ}$ 5046512-94.2016.4.04.7000/PR, Juiz Sérgio Moro, Curitiba, 12 de julho de 2017

${ }^{88}$ SITE da Câmara dos Deputados. camara. Disponivel em:

$<$ https://www.camara.leg.br/noticias/545896-camara-tem-243-deputados-novos-e-renovacao-de-473/>.

${ }^{89}$ SITE da Câmara dos Deputados. camara. Disponivel em:

$<$ https://www.camara.leg.br/noticias/545853-indice-de-renovacao-no-senado-e-de-87-46-dos-54eleitos-sao-novatos/>.
} 
um discurso crítico a Operação Lava Jato no Brasil realizado no parlamento italiano, o jurista italiano Luigi Ferrajioli afirmou:

Tivemos um impeachment que destituiu uma presidente com base apenas num clamor de desconfiança, porque não houve nenhum processo jurídico em termos reais, nenhum contraditório.

Foi uma lesão gigantesca aos direitos dos cidadãos! $!^{90}$

Ante o exposto, este capítulo tentou percorrer alguns elementos considerados essenciais para a formação do inimigo político e suas consequências jurídicas e políticas.

Essa construção bélica-binária, que permeou os dois marcos brasileiros relacionados ao combate à corrupção (Mensalão e Lava Jato), e relaciona-se diretamente com a realidade da sociedade do espetáculo apontada por Rubens Casara. O afastamento de garantias constitucionais em nome dessa guerra travada no Judiciário é apoiado por uma sofrida sociedade embebida na lógica de que os fins justificam os meios. É nesse contexto que ocorre o avanço do Estado Policial no Brasil, com festejos e aplausos de parte da população que pensa que essas medidas só serão utilizadas contra o inimigo.

\footnotetext{
${ }^{90}$ Em discurso proferido no dia 11 de abril de 2017 no Parlamento italiano. Fonte: https://www.ocafezinho.com/2017/04/20/exclusivo-o-antologico-discurso-de-ferrajoli-contra-sergiomoro-e-o-impeachment/
} 


\section{Conclusão}

O presente trabalho buscou fazer uma análise histórica dos elementos comuns entre o inimigo e a criminalização das organizações criminosas e realizar uma análise de políticas contemporâneos que cercam a seletividade com que se operam as medidas repressivas ao crime organizado. $\mathrm{Na}$ atual quadra histórica punitiva brasileira dois inimigos se destacam aos olhos da Justiça: o traficante de drogas e o corrupto, ambos tratados como "guerras" travadas dentro e fora do Judiciário.

Conforme preconizado na tese de Jakobs ${ }^{91}$, o direito brasileiro não atua da mesma forma quando se trata desses inimigos. Garantias são afastadas desses indivíduos nocivos, o que resulta em um verdadeiro vale-tudo jurídico, em que os fins condenatórios justificam os meios abusivos, tudo isso sob a bandeira da defesa social.

Apesar de tratarem de bens jurídicos distintos, ambos os inimigos são considerados perigosos à sociedade por serem integrantes de organizações criminosas. Importante ressaltar o fator conspiratório de origem norte-americana inerentes ao entendimento do crime organizado.

No caso das drogas esse fator fica bem evidente. $\mathrm{O}$ modelo altamente repressivo acerca desse delito sem vítimas e que fere a saúde pública só pode ser justificado pela incidência do crime organizado e de seu poder altamente nocivo. Esse discurso se utiliza do medo para atuar ostensivamente sobre as camadas mais vulneráveis da população.

Apesar desse contexto narrado acerca do tráfico de drogas muito permeado pelo senso comum, o que se percebe é uma realidade bem diferente.

\footnotetext{
${ }^{91}$ JAKOBS, G.; MELIÁ, M. C.; MELIÁ, C. Direito Penal do Inimigo: noções e críticas. $2^{\text {a }}$. ed. Porto Alegre: Livraria do advogado, 2007.
} 
O perfil dos presos por tráfico de drogas não diz respeito ao paradigma mafioso clássico, mas de uma realidade muito mais miserável.

Assim se atua na política de Guerra as drogas, se anuncia uma perseguição ao indivíduo poderoso e perigoso, mas a realidade demonstra a seletividade, letalidade e a finalidade real dessa política, a de regulação social dos mais vulneráveis.

Já no combate às organizações criminosas de colarinho branco, condensado no país na figura do político corrupto, a intenção possui uma natureza política. Essa cruzada de cunho moral teve duas etapas, ambas marcadas por pela espetacularização em que se deram os processos.

Enquanto a Ação penal 470 fez com que germinasse a ideia do inimigo político no que tange o Partido dos Trabalhadores, o que se viu na Operação Lava Jato foi, não só o reforço desse imaginário, como sua extensão para toda a “classe política”. A renovação política ocorrida nas eleições de 2018 evidencia isso.

Essa renovação no meio de um contexto de ódio a política resultou na expansão de discursos de cunho não democrático. Tais discursos demonstraram ter enorme popularidade na sociedade brasileira, que muitas vezes parece se 'esquecer' dos períodos ditatoriais já vividos no país, visto que constantemente parece querer flertar com esses momentos novamente.

De origens e finalidades diversas, as guerras travadas no Brasil atualmente são construídas sempre com base na demonização de um inimigo, este historicamente selecionado afim de justificar a ampliação de políticas repressivas.

O presente trabalho não tem o intuito de realizar qualquer tipo de glamourização dos crimes aqui discutidos. Tanto a corrupção, quanto as drogas devem ser encaradas como problemas de inegáveis malefícios sociais. Contudo, buscou-se demonstrar que as políticas repressivas adotadas pelo Estado se mostram mais danosas à sociedade que os problemas que buscam combater. 
Importante destacar que a figura do inimigo não é compatível no Estado de direito previsto na Constituição Federal e qualquer idealização nesse sentido merece ser combatida. Identificar elementos autoritários e suas raízes, conforme procurou fazer no presente artigo, são essenciais para possibilitar o exercício da real finalidade do direito penal, a de contenção estatal. 


\section{BIBLIOGRAFIA}

ANITUA, Gabriel Ignácio. Histórias dos pensamentos criminológicos. Rio de Janeiro: Revan: Instituto Carioca de Criminologia, 2008.

BALTHAZAR, Ricardo.; BIANCHI, Paula. Mensagens apontam que Moro interferiu em negociação de delações. Foha de São Paulo, São Paulo, 18 Julho 2019. Disponivel em:

$<$ https://www1.folha.uol.com.br/poder/2019/07/mensagens-apontam-quemoro-interferiu-em-negociacao-de-delacoes.shtml $>$.

BALTHAZAR, Ricardo; MORO MARTINS, Rafael. Moro achava fraca delação de Palocci que divulgou às vésperas de eleição, sugerem mensagens. Folha de São Paulo, São Paulo, 29 Julho 2019. Disponivel em:

$<$ https://www1.folha.uol.com.br/poder/2019/07/moro-achava-fraca-delacaode-palocci-que-divulgou-as-vesperas-de-eleicao-sugerem-mensagens.shtml $>$.

BRANDT, Ricardo. Delação de Alberto Youssef desencadeou a Lava Jato. Estadão, São Paulo, 23 Setembro 2018. Disponivel em:

$<$ https://politica.estadao.com.br/noticias/geral,delacao-de-alberto-youssefdesencadeou-a-lava-jato,70002516081>.

CASARA, Rubens R. Estado pós-democrático: neo-obscurantismo e gestão dos indesejáveis. Rio de Janeiro: Civilização Brasileira, 2018. 240 p.

COELHO, G. CNJ pede explicações a Moro sobre divulgação da delação de Palocci. Consultor Jurídico, 4 outubro 2018. Disponivel em:

$<$ https://www.conjur.com.br/2018-out-04/cnj-explicacoes-moro-divulgacaodelacao-palocci>.

D'IPPOLITO, F.; FIGUEIREDO, M. Mani Pulite Operação Mãos Limpas - 25 anos depois. Migalhas, novembro 2017. Disponivel em:

$<$ https://www.migalhas.com.br/dePeso/16,MI269664,51045-

Mani+Pulite+Operacao+Maos+Limpas+25+anos+depois $>$.

ACORDOS na justiça criminal dos EUA chegam a 95\%. Estado de Minas, Minas Gerais, 30 jan. 2019. Disponivel em:

$<$ https://www.em.com.br/app/noticia/politica/2019/01/30/interna_politica,1026 086/acordos-na-justica-criminal-dos-eua-chegam-a-95.shtml $>$.

DA CRUZ, J. H. T.; AZEVEDO, G. A política proibicionista e o mercado ilícito de drogas. Revista Brasileira de Sociologia do Direito, Porto Alegre, v. 2, p. 99-108, jan./jun. 2015. 
D'ELIA FILHO, O. Z. Acionistas do nada: quem são os traficantes de droga. $3^{\mathrm{a}}$. ed. Rio de Janeiro: Revan, 2007. 140 p.

DOMENICI, T.; BARCELOS, I. Negros são mais condenados por tráfico e com menos drogas em São Paulo. Agência Pública. Disponivel em:

$<$ https://apublica.org/2019/05/negros-sao-mais-condenados-por-trafico-e-commenos-drogas-em-sao-paulo/>.

ESCOHOTADO, Antonio. Historia general de las drogas. $7^{\mathrm{a}}$. ed. Madrid: Alianza Editorial, 1998.

FARIAS, Lindbergh Relatório Final CPI assassinato de jovens. Senado Federal. [S.1.], p. 155. 2015.

FLAUZINA, A. L. P. Corpo Negro Caído no chão: O Sistema Penal e o Projeto Genocida do Estado brasileiro. Brasília: [s.n.], 2006.

GILMAR critica Lava-Jato: "Organização criminosa para investigar pessoas". Correio brasiliense, Brasília, 04 Agosto 2019. Disponivel em:

$<$ https://www.correiobraziliense.com.br/app/noticia/politica/2019/08/04/intern a_politica,775355/gilmar-mendes-chama-lava-jato-de-organizacao-criminosaem-entrevista.shtml>.

HARARI, Yuval. Sapiens - Uma Breve História da Humanidade. 29a . ed. [S.1.]: Harper, 2011.

JAKOBS, Gunther.; MELIÁ, Manuel. Cancio. Direito Penal do Inimigo: noções e críticas. $2^{\mathrm{a}}$. ed. Porto Alegre: Livraria do advogado, 2007.

LOPES JR. , Aury. Direito Processual Penal. 12ª ed. São Paulo: Saraiva, 2015.

MACHADO, Marta Rodriguez de Assis Edmund Mezger e o direito penal de nosso tempo. Revista Direito FGV, São Paulo, v. 1, n. 1, p. 153-159, Maio 2005.

MANSO, Bruno Paes; DIAS, Camila Nunes A Guerra:A ascensão do PCC e o mundo do crime no Brasil. São Paulo: Todavia, 2018.

MAURÍCIO, Juliete Laura Rocha Positivismo Criminológico: as ideias de Lombroso, Ferri e Garófalo. Olhares Plurais - Revista eletrônica Multidisciplinar, Maceió, v. 1, n. 12, p. 59-69, julho 2015.

NUCCI, Guilherme. D. S. Organização Criminosa. $2^{\mathrm{a}}$. ed. Rio de Janeiro: Forense, 2015.

ORWELL, George. 1984. São Paulo: Companhia das Letras, 2009. 414 p. 
PÁDUA, Luciano. Dos 163 condenados na Lava Jato de Curitiba, 40\% são delatores. JOTA, São Paulo, Abril 2019. Disponivel em:

$<$ https://www.jota.info/justica/lava-jato-curitiba-condenados-delatores$15042019>$.

PARA 57\% dos brasileiros, 'bandido bom é bandido morto', diz Datafolha. Portal de notícias G1, São Paulo, 02 novembro 2016. Disponivel em: $<$ http://g1.globo.com/sao-paulo/noticia/2016/11/para-57-dos-brasileirosbandido-bom-e-bandido-morto-diz-datafolha.html $>$.

PIERRY, Flávia. Joaquim Barbosa é o "justiceiro" nas redes sociais. O Globo, Brasília, 07 Setembro 2012. Disponivel em:

$<$ https://oglobo.globo.com/brasil/joaquim-barbosa-o-justiceiro-nas-redessociais-6024965>.

SANTOS, Juarez Cirino. Palestra proferida no 1o Fórum Latino-Americano de Política Criminal, promovido pelo IBCCRIM, de 14 a 17 de maio de 2002, em Ribeirão Preto, SP.

SEMER, Marcelo Sentenciando o tráfico: o papel dos juízes no grande encarceramento. $1^{\mathrm{a}}$. ed. São Paulo: Tirant, 2019. 340 p.

SITE da Câmara dos Deputados. camara. Disponivel em:

$<$ https://www.camara.leg.br/noticias/545853-indice-de-renovacao-no-senadoe-de-87-46-dos-54-eleitos-sao-novatos/>.

SITE da Câmara dos Deputados. camara. Disponivel em:

$<$ https://www.camara.leg.br/noticias/545896-camara-tem-243-deputadosnovos-e-renovacao-de-473/>.

VILLELA, Gustavo. Pito do Pango' na década de 30, maconha era vendida em herbanários do Rio. O Globo, Rio de Janeiro, 23 julho 2014. Disponivel em: $<$ https://acervo.oglobo.globo.com/em-destaque/pito-do-pango-na-decada-de30-maconha-era-vendida-em-herbanarios-do-rio-13352181>.

VOCÊ matou meu filho: homicídios cometidos pela polícia na cidade do Rio de Janeiro. Anistia Internacional, Rio de Janeiro, 2015.

ZAFFARONI, Eugênio Raúl. "Crime Organizado": uma categoria frustrada. In: Discursos sediciosos: crime, direito e sociedade. Rio de Janeiro:

Relume Dumará, v. 1, 1996. p. 45-67.

ZAFFARONI, Eugênio Raúl. O Inimigo no Direito Penal. Tradução de Sérgio Lamarão. $2^{\mathrm{a}}$. ed. Rio de Janeiro: Revan, 2007. 
ZAFFARONI, Eugênio Raúl; BATISTA, Nilo ; ALAGUA, Alejandro; Slokar, Alejandro Direito Penal Brasileiro: primeiro volume - Teoria Geral do Direito Penal. 4a . ed. Rio de Janeiro: Revan, v. I, 2017 
